\title{
Impact of polyphenols and polyphenol-rich dietary sources on gut microbiota composition
}

Usune Etxeberria $^{1}$, Alfredo Fernández-Quintela ${ }^{2,3}$, Fermín I. Milagro, ${ }^{1,3}$, Leixuri Aguirre $^{2,3}$, J. Alfredo Martínez ${ }^{1,3}$, María P. Portillo ${ }^{2,3}$

${ }^{1}$ Department of Nutrition and Food Sciences, Physiology and Toxicology, University of Navarra, Pamplona, Spain

${ }^{2}$ Nutrition and Obesity Group. Dpt. Nutrition and Food Sciences. Faculty of Pharmacy. University of the Basque Country. Paseo de la Universidad, 7. 01006 Vitoria (Spain)

${ }^{3}$ CIBER de Fisiopatología de la Obesidad y Nutrición (CIBERobn), Instituto de Salud Carlos III, Spain

*Corresponding author: Dr. Alfredo Fernández-Quintela, Telephone +34-945-013066, fax+34-945-013014, email alfredo.fernandez@ehu.es 


\begin{abstract}
Gut microbiota plays a key role in host physiology and metabolism. Indeed, the relevance of a well-balanced gut microbiota composition to an individual's health status is essential for the person's well-being. Currently, investigations are focused on analyzing the effects of pre- and probiotics as new therapeutic tools to counteract the disruption of intestinal bacterial balance occurring in several diseases. Polyphenols exert a wide range of beneficial health effects. However, although specific attention has been paid in recent years to the function of this "biological entity" in the metabolism of polyphenols, less is known about the modulatory capacity of these bioactive compounds on gut microbiota composition. This review provides an overview of the latest investigations carried out with pure polyphenols, extracts rich in polyphenols and polyphenol-rich dietary sources (such as cocoa, tea, wine, soy products and fruits), and critically discusses the consequences to gut microbiota composition which are produced.
\end{abstract}

Keywords: Gut microbiota, polyphenols, health, interactions 


\section{Introduction}

Polyphenols are members of a very large family of plant-derived compounds that show an extensive variety of chemical structures. They are classified as flavonoids and nonflavonoids. Among the flavonoids, various groups can be distinguished: flavonols, flavan-3-ols (monomeric and polymeric structures), flavones, isoflavones, flavanones and anthocyanidins. Among non-flavonoids we find stilbenes, hydrolysable tannins and phenolic acids. ${ }^{1}$ The polyphenolic profile of vegetables and fruits very much depends on the type of plants, on the conditions under which these plants are grown, on harvest conditions and how these products are stored.

Polyphenols can have beneficial effects on human health, and thus their study has become an increasingly important area of human nutrition research. A great number of epidemiological studies have shown that the consumption of diets rich in fruits and vegetables is associated with a reduction in the risk of suffering chronic diseases, such as cardiovascular diseases, specific cancers or neurodegenerative diseases. In order to confirm these observations, numerous intervention trials have been conducted in recent years. The beneficial effects of phenolic compounds on different health issues have been reviewed elsewhere. ${ }^{2}$

Taking into account current scientific evidences about the beneficial effects induced by polyphenol intake, despite the low bioavailability of these molecules, further studies are required to analyze whether polyphenol metabolites contribute to the effects of their parent compounds. However, the investigations reported concerning this topic are scarce. In this context, the role of gut microbiota, which determines to some extent the polyphenol metabolite profile, is an important issue to be addressed. ${ }^{3,4}$ The action of gut 
microbes on polyphenols leading to the production of metabolites with diverse physiological relevance has been also analyzed in the recent years. ${ }^{5}$

This review aims to highlight the impact of phenolic compounds, either as pure compounds or as food constituents, on gut microbiota composition and intends to offer an update of the recent in vitro and in vivo evidence which demonstrates the interaction existing between gut microbes and polyphenols with health impact.

\section{Gut microbiota and health}

The intestine is the largest reservoir of human flora, which achieves concentrations of up to $10^{11}$ or $10^{12}$ cells/g and consists of a complex microbial community residing the gut called microbiota. The human body has about 100 trillion microorganisms in the intestine, which is ten times higher than the total number of human cells in the body. Only a minority of the species that inhabit the human colon has been identified so far, but modern molecular methods such as broad-range sequencing of 16S ribosomal RNA from amplified bacterial nucleic acids extracted from faeces or biopsies, are being used nowadays to identify and classify intestinal bacteria ${ }^{6}$.

Bacteria make up most of the flora in the colon, where around 300-500 different species live. ${ }^{6}$ The most common bacteria are Bacteroides which constitute around $30 \%$ of all bacteria in the gut, followed by Clostridium, Prevotella, Eubacterium, Ruminococcus, Fusobacterium, Peptococcus, and Bifidobacterium. Escherichia and Lactobacillus are also present, but at lesser extent. ${ }^{7}$ It seems that $99 \%$ of the bacteria come from about 30 or 40 species. $^{7}$

It has been reported that diet has a major influence on gut microbiota and is able to modify their impact on health, with either beneficial or deleterious consequences. ${ }^{8}$ Thus, levels of Prevotella are enriched in children who have had a high-fiber $\operatorname{diet}^{9}$, as well as 
in children and adults whose diet is dominated by plant-derived polysaccharide foods, such as maize and cassava. By contrast, the microbiota of people with a long-term diet rich in animal protein and saturated fat has more Bacteroides. ${ }^{10}$ These changes can be explained by fiber content of the diet. The increase in colonic fermentation results in a decrease in the $\mathrm{pH}$, from 6.5 to 5.5 , due to the high concentrations of short-chain fatty acids. This decrease in the $\mathrm{pH}$ has a profound selective effect upon the colonic microbial community in fermentor simulations supplied with soluble polysaccharides, with a tendency to suppress Bacteroides spp. and to promote butyrate-producing grampositive bacteria. ${ }^{11}$ However, long-term periods (8-9 weeks) of dietary patterns are needed to induce changes in the microbiota of individuals. ${ }^{12}$

During the metabolism of foods and xenobiotics, the host and its gut microbiota coproduce a large amount of small molecules, many of which play critical roles in shuttling information between host cells and the host's microbial symbionts (cross-talk). In this context, alterations in the microbiome, dysbiosis, modulate the metabolic phenotype of the host, and greatly influence host biochemistry and susceptibility to diseases. ${ }^{13}$ Indeed, it has been proposed that gut microbiota are involved in appetite control, energy balance, obesity, diabetes, immune function, allergies, behavioral perturbations, cardiovascular disease and cancers, such as stomach cancer. ${ }^{8}$

\section{Polyphenols and gut microbiota interactions}

The percentage of polyphenol absorption is very low ${ }^{14}$ and as much as $90 \%$ of these compounds persist into the colon. There, they are metabolized via esterase, glucosidase, demethylation, dehydroxylation and decarboxylation activities of bacteria, ${ }^{15}$ resulting in smaller metabolites such as phenolic acids and short chain-fatty acids, some of which can be absorbed across the intestinal mucosa. Interestingly, the microbial bioconversion 
capacity of each individual influences the final metabolites produced and impacts on their bioavailability. Indeed, since all individuals have their own unique signature of intestinal microbiota, which can make an analogy with a fingerprint, human intestinal microbiota composition can modulate the polyphenol impact on host health. ${ }^{15,16}$

On the other hand, polyphenols and their metabolites can affect the intestinal ecology modulating microbiota. ${ }^{15}$ In this sense, several phenolic compounds have been identified as potential antimicrobial agents with bacteriostatic or bactericidal actions. Furthermore, they could also act as inhibitors of infection-causing bacteria within cells of the intestinal and urinary tracts, suggesting that some phenolic compounds have potential to be applied as antimicrobial agents against human infections. ${ }^{15}$

Despite these positive effects, it is important not to forget that excessive amounts of polyphenols may also inhibit the growth of colonic beneficial microbiota, which is responsible for bioconversion of polyphenols, and thus indirectly interfere with their own bioavailability. Consequently, dietary supplementation may exert a non-desirable effect on human health instead of supporting it. ${ }^{16}$

\section{Influence of phenolic compounds in gut microbiota composition}

The majority of studies encompassing the influence of phenolic compounds on gut microbes have been focused on their anti-microbial activity. However, the concept of polyphenols as potential prebiotic candidates could be considered as a newly emerging concept.

Interestingly, a number of in vitro and in vivo (in animals and humans) studies showing the influence of dietary polyphenols on gut-inhabiting bacteria have been published in recent years. 


\section{Flavonoids}

\section{Flavanones and flavonols}

The impact of some flavanones (naringenin, naringin, hesperetin, hesperidin) and flavonols (quercetin and rutin), on specific intestinal microbial representatives was screened in vitro by Duda-Chodak. ${ }^{16}$ For this purpose, pure cultures of 6 bacteria species (Bacteroides galacturonicus, Lactobacillus sp., Enterococcus caccae, Bifidobacterium catenulatum, Ruminococcus gauvreauii and Escherichia coli) were inoculated with pure polyphenols at final concentrations of 4,20 and $50 \mu \mathrm{g} / \mathrm{mL}$ in the case of quercetin and at 20, 100 and $250 \mu \mathrm{g} / \mathrm{mL}$ for the rest of the compounds. Naringenin and quercetin exerted a complete and dose-dependent inhibitory effect on the growth of all analyzed bacterial species, whereas this effect was weaker for hesperetin. A higher inhibitory effect of the aglycones, compared to that of the glycosides (naringin, rutin and hesperidin), was demonstrated. ${ }^{16}$ The fact that flavanone glycosides were unable to exert any antimicrobial activity was explained by the dependency of the potential of these compounds on the sugar presence/absence in the moiety.

In another in vitro study conducted by Kawabata et al. ${ }^{17}$ Bifidobacterium adolescentis, one of the probiotic species usually identified in the intestine of both children and adults, was co-cultured with different flavonols (galangin, kaempferol, quercetin, myricetin and fisetin) and the growth rate measured. ${ }^{17}$ All the flavonoids studied, except galangin, showed little or no anti-bacterial effect. In addition, when these conditioned media were exposed to a nitric oxide (NO) production inhibition assay, the co-culture of B. adolescentis with galangin (54\%), quercetin (50\%) and fisetin (76\%) decreased NO 
synthesis, suggesting an improvement in flavonol anti-inflammatory capacity by $B$. adolescentis. $^{17}$

Backing up these findings, another study tested pure polyphenols at concentrations ranging from $62.5-1000 \mu \mathrm{g} / \mathrm{mL}$ and their influence on the viability of four bacterial strains (Escherichia coli, Staphylococcus aureus, Salmonella typhimurium and Lactobacillus rhamnousus) was assessed. ${ }^{18}$ All polyphenols, except rutin, induced a decrease in bacterial growth, but specifically quercetin (flavonol) and naringenin (flavanone) presented the highest anti-bacterial activities with the lowest minimum inhibitory concentration (MIC) values. Although Gram-negatives tested had similar sensitiveness to polyphenols, within Gram-positive populations, S. aureus was the most sensitive, while L. rhamnosus required a MIC of at least $125 \mu \mathrm{g} / \mathrm{mL} .^{18}$

\section{Flavanols}

In a study that investigated the effect of flavanol monomers, namely (-)-epicatechin and $(+)$-catechin, on the growth of specific bacterial populations, a marked overgrowth of beneficial bacterial groups was noted when microbiota was exposed to $150 \mathrm{mg} / \mathrm{L}$ or $1000 \mathrm{mg} / \mathrm{L}$ of $(+)$-catechin. ${ }^{19}$ Both concentrations promoted the growth of Eubacterium rectale-Clostridium coccoides, and the lowest concentration was able to induce that of Lactobacillus spp. and Bifidobacterium spp. Moreover, (+)-catechin inoculation at 150 $\mathrm{mg} / \mathrm{L}$ induced the growth of Escherichia coli and the $1000 \mathrm{mg} / \mathrm{L}$ concentration decreased that of Clostridium histolyticum. A significant increase in the growth of Eubacterium rectale- Clostridium coccoides was also reported with the inoculation of ()-epicatechin at $150 \mathrm{mg} / \mathrm{L}$ concentration. ${ }^{19}$ The inhibitory potential of (+)- catechin at concentrations raging 20 to $250 \mu \mathrm{g} / \mathrm{mL}$, on specific intestinal microbial representatives 
was reported to be powerless as it was only able to slightly slow down the growth of $B$. catenulatum (MIC $>250 \mu \mathrm{g} / \mathrm{mL}$ ), but promoted the growth of E. caccae. ${ }^{16}$

Polyphenon $G$ powder, a purified preparation of tea-derived catechins, was also reported to induce a significant increase in lactobacilli and a marked decrease in Enterobacteriaceae in broiler chickens. ${ }^{20}$

The implication of the principal tea phenolic aglycones, epicatechin, catechin, 3-Omethylgallic acid, gallic acid and caffeic acid, on pathogenic, commensal and probiotic intestinal bacteria was investigated in an in vitro study by Lee et al. ${ }^{21}$ In agreement with the effects previously mentioned, these compounds suppressed the growth of pathogens like Clostridium perfrigens, Clostridium difficile, and Bacteroides spp., with commensal anaerobes (Clostridium spp. and Bifidobacterium spp.) and probiotics (such as Lactobacillus spp.) being affected in a much lower extent. Caffeic acid was evidenced to be the strongest inhibitor, especially for Eschericia coli, Salmonella, Pseudomonas, Clostridium and Bacteroides. $^{21}$

\section{Isoflavones}

Gut microbiota composition has been reported to play a key role in the degradation of isoflavones and studies are being conducted to unveil the bacterial strains responsible. Nonetheless, studies analyzing the effect of isoflavone supplementation on gut microbiota composition are scarce. Clavel et al. ${ }^{22}$ found that isoflavone supplementation $(100 \mathrm{mg} / \mathrm{d})$ to postmenopausal women during two months, produced a bifidogenic effect with increases in Bifidobacterium species. ${ }^{22}$ In this trial, isoflavones were reported to alter dominant bacterial communities with increases in Clostridium coccoides- Eubacterium rectale (Erec) cluster, Faecalibacterium prasnutzii subgroup and Lactobacillus-Enterococcus group. However, unlike Bifidobacterium species, the 
concentrations of the Erec-cluster were suggested to be linked to the obtention of equol, an intestinal metabolite from daidzein.

\section{Condensed tannins (proanthocyanidins)}

Condensed tannins, which are also called proanthocyanidins, are present in a broad number of higher plant species. Regarding the effect of these compounds on gut microbiota, the effects of diet supplementation with low-tannin $(0.7 \%)$ and high-tannin $(2.0 \%)$ diets were assessed in rats by Smith et al. ${ }^{23}$ Shifts in bacterial populations of faeces were analyzed by DNA fingerprinting and bacterial cultivation and enumeration. The authors concluded that the most predominant groups in condensed-tannin supplemented animals were those belonging to Enterobacteriaceae, BacteroidesPrevotella- Porphyromonas and the Bacteroides fragilis group. ${ }^{23}$

\section{Nonflavonoids}

\section{Stilbenes}

The antimicrobial effects of resveratrol (3,5,4'-trihydroxy-trans-stilbene) against several pathogenic agents has been reported in vitro. When this compound was administered to a DSS-induced colitis rat model, a significant increase in lactobacilli and bifidobacteria, as well as decrease of enterobacteria, was observed after 20 days. $^{24}$

\section{Hydrolysable tannins (ellagitannins)}

Ellagitannins, a type of hydrolysable tannin, are hydrolized in vivo and releases ellagic acid, whose metabolism by gut microbiota results in urolithin production ${ }^{25}$. The effect of these tannins on the growth of intestinal bacteria is limited and generally their antimicrobial potential has been evaluated in vitro. In relation to this, Bialonska et al. ${ }^{26}$ 
analyzed the effect of a commercial extract of pomegranate at $0.01 \%$, as well as the effect of its main constituents $(0.05 \%)$ on the growth of several intestinal bacteria by liquid culturing. A strong inhibition capacity was observed with punicalagins and ellagic acid, especially against Clostridium species, while a repression in pathogenic Staphylococcus aureus growth was only obtained with the pomegranate extract and punicalagins. Interestingly, the growth of probiotic lactobacilli and bifidobacteria was less affected. ${ }^{26}$ Moreover, the same group aimed to prove whether this trend was maintained using a fermentation batch-culture system inoculated with faecal samples from healthy individuals, which better simulate conditions from colonic region. In this experiment, pomegranate extract was able to produce an increment on total bacterial number, enhancing the growth of Bifidobacterium spp., Lactobacillus and Enterococcus groups, while no effect was observed for C. histolyticum group. ${ }^{27}$ In a different study, the growth of Escherichia coli (half maximal inhibitory concentration, $\mathrm{IC}_{50}=9.2 \mu \mathrm{M}$ ) and Pseudomonas aeruginosa $\left(\mathrm{IC}_{50}=3.2 \mu \mathrm{M}\right)$ was suppressed by punicalagins and gallagic acid, while ellagic acid and punicalins did not exhibit any antimicrobial activity. The authors could not correlate these results with the structural differences of the compounds. ${ }^{28}$

\section{Polyphenol-rich dietary sources and gut microbiota composition}

\section{Cocoa}

Cocoa, a product derived from Theobroma cacao L. (Sterculiaceae), is rich in flavan-3ols, in the form of monomeric (-)-epicatechin and (+)-catechin, as well as type- B proanthocyanidins. The fact that cocoa polyphenols ingestion could affect diseases, such as hypertension, oxidative stress, cancer, atherosclerosis, diabetes, and diverse central nervous system disorders, and the fact that these disorders have also been linked 
to gut microbiota, has opened a research gate to investigating the effect of cocoa or chocolate intake on gut microbiota. In this regard, the faecal microbiota composition was analyzed after a high and continuous $(10 \% \mathrm{w} / \mathrm{w})$ cocoa intake in female Wistar rats. ${ }^{29}$ The authors reported significantly lower levels of Bacteroides, Staphylococcus and Clostridium genera at the end of the intervention. Moreover, reductions in Clostridium species were found to correlate with weight loss and body mass index (BMI) z-score. ${ }^{29}$

A human intervention study conducted with low-cocoa flavanol (LCF, $29 \mathrm{mg}$ ) and highcocoa flavanol (HCF, $494 \mathrm{mg}$ ) drinks over 4 weeks, described a significant increase in Lactobacillus spp. $(P<0.001)$ and Bifidobacterium spp. $(P<0.001)$ when the HCF was compared to the control LCF beverage. ${ }^{30}$ This condition was suggested to be partly responsible for the reductions observed in C-reactive protein $(\mathrm{mg} / \mathrm{mL})(\mathrm{CRP})$ plasma levels $(-30 \%)$. On the other hand, a significant decrease in $C$. histolyticum group $(P<$ 0.001) was stated, a group that includes $C$. perfringens pathogen, an agent contributing to a wide range of human diseases. ${ }^{30}$

\section{Tea}

Flavonoids in tea (from the plant Camellia sinensis) occur in large quantities, the major classes being catechins, including epicatechin, epigallocatechin, epicatechin-3-gallate, and epigallocatechin-3-gallate. Moreover, flavanols, such as quercetin, kaempferol, myricetin and their glycosides are also found. The linkage between tea consumption and gut microbiota as a possible explanation for its contribution to well-being is under investigation. Ahn et al., ${ }^{31}$ reported that green tea extracts (GTE) repressed the growth of Clostridium bifermentans, C. difficile, C.innocuum, C. paraputrificum, C. perfringens and C. ramosum, while encouraging the growth of Bifidobacterium spp. in vitro. ${ }^{31}$ In an 
in vitro study conducted by Kemperman et al., ${ }^{32}$ the antimicrobial effect of a black tea extract was analyzed by traditional culturing and $\mathrm{qPCR}$, and its impact on microbial community was also assessed by PCR-DGGE and 16S rDNA measurements. ${ }^{32}$ Several animal studies conducted in $\operatorname{pigs}^{33}$ and in calves ${ }^{34}$ concluded that tea polyphenols produced an enhancement in animals' intestinal microbiota. Thus, pigs that received $0.2 \%$ of tea polyphenols for 2 weeks showed a significant decrease in total bacteria and bacteroidaceae and a tendency to decrease in C. perfringens. By contrast, a significant increase in Lactobacilli was found ${ }^{33}$. Similarly, two types of GTE were tested in vitro (GTE-1 and GTE-2, polyphenol contents $>60 \%$ and $>80 \%$, respectively) and MICs were determined for diverse pathogenic bacteria. As a result of these in vitro analyses, a stronger inhibitory capacity of GTE-2 was concluded, assuming that the higher amounts of (-)-epigallocatechin gallate, (-)-gallocatechin gallate and (-)-epicatechin gallate might be responsible for the observed reduction in bacterial growth. Furthermore, within the large variability of MICs detected for the tested species, the total counts of Bifidobacterium spp. and Lactobacillus spp. were significantly higher in the test group. In the same study, the growth rate reduction of $C$. perfringens was faster in calves supplemented with GTE, supporting the potential of GTE to prevent the growth of pathogenic bacteria and to improve microflora balance. ${ }^{34}$

In humans, a product containing $70 \%$ of tea polyphenols (Sunphenon ${ }^{\circledR}$, which included (+)-catechin, (-)-epicatechin, (+)-gallocatechin, (-)-epigallocatechin, (-)-epicatechin gallate, (-)-gallocatechin gallate, and (-)-epigallocatechin gallate) was administered $(0.4 \mathrm{~g} /$ volunteer) 3 times per day, for 4 weeks, which was equivalent to 10 cups of concentrated green tea. Results indicated that C. perfringens and other Clostridium spp. were significantly reduced during the tea polyphenol intake periods, whereas percentages of Bifidobacterium spp. in total faecal counts markedly increased. ${ }^{35}$ More 
recently, bifidobacteria showed a trend to increase in 10 volunteers who drank green tea for 10 days. $^{36}$ In a different study, the effect of $4 \%$ green tea powder (GT) supplement with or without the addition of Lactobacillus plantarun DSM 15313 (Lp), was evaluated on microbiota of small intestine and caecum of high-fat fed mice. This study showed a synergestic effect with significant increases in Lactobacillus group and bacterial diversity, in both, small intestine and caecum, after 22 weeks. ${ }^{37}$

\section{Wine}

Benefits coming from the moderate consumption of red wine (RW) have been mostly attributed to its phenolic compounds, consisting of a complex mixture of flavonoids, such as flavan-3-ols and anthocyanins, but also, of nonflavonoids, such as resveratrol, cinnamates and gallic acid. Similarly to the polyphenols derived from other food products, wine polyphenols have also been stated to display a selective modulation of gut microbiota ${ }^{32}$. Thus, Dolara et al. ${ }^{38}$ reported changes in the main bacterial strains of wine polyphenol-treated F344 rats (50 mg/kg for 15 weeks) compared to the control-fed rats. The wine polyphenolic extract contained $4.4 \%$ anthocyanins, $0.8 \%$ flavonols, $2.0 \%$ phenolic acids, $1.4 \%$ catechin, $1.0 \%$ epicatechin and $28 \%$ proanthocyanidin. Bacteroides, Lactobacillus and Bifidobacterium spp. were more predominant in faeces of polyphenol-treated rats, whereas Bacteroides, Clostridium and Propionibacterium spp. prevailed in control-fed rats' faeces. The authors underlined the potentiality of wine polyphenols to simulate the favourable effects of fibres and prebiotics on the colonic bacterial content. ${ }^{38}$ An in vitro batch culture fermentation model carried out with human faecal microbiota aimed to observe the bacteria- polyphenol interactions implicated in the colonic metabolism of RW polyphenols. ${ }^{39}$ In this study, the slight inhibition observed in Clostridium histolyticum were in concordance with the conclusions drawn 
with monomeric flavan-3-ols and cocoa flavan-3-ols in previously mentioned batch culture models. ${ }^{19,30}$ Nevertheless, the lack of positive effects found on the growth of Lactobacillus/Enterococcus spp. in this experiment, ${ }^{39}$ was ascribed to the lower concentrations of flavan-3-ol compounds provided $(20.94 \mathrm{mg} / \mathrm{L})$ compared to the 219 mg/L used by Tzounis et al. ${ }^{19,30}$ In an intervention study, Queipo-Ortuño et al. ${ }^{40}$ investigated the changes produced in the faecal microbiota of ten healthy human volunteers after the consecutive intake of RW, dealcoholized red wine (DRW), and gin. After a washout period of two weeks, the small number of participants enrolled to the study was crossed from one treatment to the other, which might help the authors having a greater statistical power. However, the fact that there were three treatments with the absence of washout periods between them was a limitation that required discussion. Based on data from the monitorization of urine resveratrol metabolites after each treatment, the authors were able to conclude that there was not any carryover from treatment to treatment, thus, this issue was discarded as a confounding factor. ${ }^{40}$ Regarding gut microbiota, differences were observed depending on the type of beverage consumed. Briefly, four mayor bacteria phyla (Proteobacteria, Fusobacteria, Firmicutes and Bacteroidetes) were markedly increased after RW intake, and relevant increases in Bifidobacterium and Prevotella species were detected. In contrast, no changes were found in Actinobacteria phyla and marked decreases were identified in the Clostridium genera and Clostridium histolyticum group with RW. Nevertheless, these effects were less pronounced or even disappeared with DRW. Interestingly, the induction of gut microbiota remodelling due to the intake of small amounts of ethanol with polyphenols, was linked to reductions in blood pressure, triglycerides, total cholesterol and CRP. ${ }^{40}$ Table 1 summarizes the main results from studies analyzing polyphenol-rich beverages and gut microbiota composition. 


\section{Soy products}

Soy products, coming from soybeans (members of Leguminosae), are rich in phytoestrogens, principally in the form of isoflavones. At this stage, a study that evaluated the impact of diverse soymilk formula consumption on the intestinal ecosystem of human overweight and obese men found a better Firmicutes to Bacteroidetes ratio in the soymilk-fed groups. ${ }^{41}$ Soymilk intake in newborns was found to slightly enlarge the number of Bifidobacterium species in the infants. ${ }^{42}$ Nevertheless, neither analyzed the isoflavone content of the soymilk or soy formula milk used; therefore, the slight modifications observed could not be attributed to specific components of the milk. The use of the Simulator of the Human Intestinal Microbial Ecosystem (SHIME) to prove the influence of a soygerm powder in the fermentative capacity of bacteria from inoculated faecal samples has been focus of interest. ${ }^{43}$ Moreover, in vivo studies with probiotic soy products have been also performed and differences on fecal microbiota have been reported. Bedani et al., ${ }^{44}$ analyzed bacterial genus composition in rats faeces that were administered the Enterococcus faecium CRL 183 probiotic microorganism with a soy product, either as a pure cell suspension or as a fermented product. Data were compared to microbial changes observed in rats treated with the unfermented soy product. In this case, no reductions in pathogenic genus such as, Clostridium spp., Bacteroides spp. or enterobacteria were concluded for the animals treated with the fermented soy products and only an enhancement in the growth of Lactobacillus spp. was obtained for the animals administered the E. faecium suspension. ${ }^{44}$ Cavallini et al., ${ }^{45}$ in contrast, performed another experiment, in which a probiotic soy product was administered to white rabbits and posterior analyses of microbiota were performed in vitro. In this case, the difference in bacterial populations obtained between fermented and unfermented products were more significant regarding 
Lactobacillus spp. and Bifidobacterium spp. populations, which might be attributed to the addition of probiotic bacteria (E. faecium CRL 183 and L. helveticus 416). In fact, it could be observed that unfermented soy products are able to reduce Clostridium species, while fermented soy products, in general, produce an enhancement in the growth of probiotic bacteria. $^{45}$

\section{Fruits}

A great deal of evidence suggests that fruits, vegetables and products coming from them, are able to significantly boost the growth of colonic friendly bacteria, as for example Bifidobacterium and Lactobacillus. Table 2 presents data about the influence of some selected fruits and soy products on gut microbiota composition.

\section{Pomegranate}

Scientific research has evidenced the high antioxidant capacity of pomegranate (Punica granatum L.) products, which has been attributed to their high content in antioxidants and anti-inflammatory bioactive compounds (ellagitannins and anthocyanins mainly) concentrated in peel, membranes and piths. In this context, experiments using batchculture fermentation systems have aimed to examine the potential of pomegranate peel extract (PPE) and punicalagins in the growth of intestinal bacterial strains. In these studies, PPE (0.01\%) inhibited the growth of C. perfringens, C. ramosum, Staphyloccoccus aureus and C. clostridioforme, but significantly enhanced the growth of $B$. breve and $B$. infantis by $275 \%$ and $241 \%$, respectively. ${ }^{26}$ In a similar study, Bialonska et al. ${ }^{27}$ stated a significant increase of total bacteria and beneficial bacteria Bifidobacterium spp. and Lactobacillus- Enterococcus group in media supplemented with PPE, which was accompanied by a marked increase in the production of short chain fatty acids. In contrast, no significant effect was observed in gut bacteria grown in 
media supplemented with punicalagins $(0.2 \% \mathrm{w} / \mathrm{v}) .{ }^{27}$ Larrosa et al. ${ }^{46}$ reported for the first time the prebiotic effect of PPE using a dextran sodium sulphate- induced colitis rat model. The intake of $250 \mathrm{mg}$ PPE/kg/day (equivalent to $2.5 \mathrm{~g}$ PPE in a $70 \mathrm{~kg}$-person) for 3 weeks increased Bifidobacterium, Lactobacillus and Clostridium counts preventing the colonization and invasion of tissues by enterobacteria including E. coli. In addition, the same results were obtained when the rats were fed synthetic urolithin A $(2.2 \mathrm{mg} / \mathrm{kg} /$ day; equivalent to $154 \mathrm{mg}$ in a $70 \mathrm{~kg}$ person), which demonstrated that the main gut microbiota- derived metabolite from pomegranate ellagitannins, urolithin A, also showed prebiotic effect. ${ }^{46}$ Neyrinck et al. ${ }^{47}$ emphasized the enhancement of the caecal pool of bifidobacteria in mice fed a high-fat diet supplemented with the PPE (rich in polyphenols, $30 \%$ ). In addition, a down-regulation of the expression of inflammatory markers (IL-1 $\beta$, IL-6, COX-2) in colon and visceral adipose tissue was demonstrated for the latter group. Therefore, a direct relationship between PPE consumption and health improvement through gut microbiota modulation was hypothesized by the authors. ${ }^{47}$

\section{Apples}

Apple contains a high amount of pectin, a polysaccharide fiber that has been described to influence intestinal microbiota, but is also rich in phenolic compounds with high antioxidant capacity. Licht et al. ${ }^{48}$ argued that changes in the microbiota of apple-fed rats should be ascribed to pectin. ${ }^{48}$ Rats that received an extraction juice from apples (total polyphenols, $829 \mathrm{mg} / \mathrm{L}$ ) for 4 weeks, instead of drinking water, showed significantly more Lactobacillus and Bifidobacterium in fresh faeces. ${ }^{49}$ The same research group also observed an increase in Bacteroidaceae species in Wistar rats' offered juice colloids isolated from apple pomace extraction juices, which presented higher contents of dietary fiber and polyphenols. ${ }^{50}$ Moreover, as previously reported, in 
a study where apple pectin $(5 \mathrm{~g} / 100 \mathrm{~g})$ and polyphenol-rich apple concentrate $(10 \mathrm{~g} / 100$ g) was given to rats, even if microbiota analyses were not conducted, a more effective biological effect was demonstrated when both components were administered in combination, implying the important role of the phenolic compounds. ${ }^{51}$

\section{Grapes}

Grape fruits are rich in polyphenols, mainly, anthocyanins, flavonols, favan-3-ols, hydroxybenzoates and phenolic acids. An in vitro study was conducted in order to analyze the potential of two grape seed flavan-3-ol fractions in the growth and metabolism of Bifidobacterium spp., Lactobacillus/Enterococcus spp., Clostridium histolyticum group, Bacteroides spp. and members of the domain Bacteria. ${ }^{52}$ The analyzed grape seed extracts (GSE) differed in their composition of monomers and oligomers. Monomeric-rich fraction of GSE (GSE-M) contained 70\% monomers and $28 \%$ procyanidins, whereas oligomeric-rich fraction of GSE (GSE-O) was composed of $21 \%$ monomers and $78 \%$ procyanidins. In spite of these composition differences, both extracts produced comparable effects on microbiota composition. For instance, a selective inhibitory action on Clostridium histolyticum was described for both fractions within 5-10 h of fermentation period, this being statistically significant only for GSE-O at $10 \mathrm{~h}$ of fermentation. During these first hours, an increase in Lactobacillus/Enterococcus group was also found in both cases, although statistical significance was only achieved for the fractions with the highest flavan-3-ol monomers fraction. ${ }^{52}$ The chromatographic characterization of grape seed fractions obtained from different extraction methods (Aqualsolv and microwave-assisted extraction), reported that fractions containing mainly monomers, like catechin and epicatechin, presented low antibacterial activity, whereas those fractions containing oligomeric units of catechins 
and epicatechins were more effective inhibiting the growth of 10 tested pathogens (Staphylococcus aureus, Pseudomonas aeruginosa, Klebsiella pneumonia, Escherichia coli, Staphylococcus epidermis, Enterococcus faecalis, Streptococcus pyogenes, Haemophilus influenzae, Enterococcus casilliflavus and Pneumococcus). ${ }^{53}$ When comparing the inhibitory capacity of grape seed extracts and grape bagasse extracts in relation to the amounts of total phenolics obtained with two different solvent extraction methods, GSE had the highest total phenolic concentration resulted from the acetone: water: acetic acid extraction. ${ }^{54}$ In another study, three commercial GSE, which differed in their flavan-3-ol profiles, were assayed to test their effect on the growth of several Lactobacillus and bifidobacteria strains. ${ }^{55}$ Briefly, a general inhibition of bacterial growth was observed as the most common response. Although dependent on the polyphenol extract composition and the bacterial strain tested, this growth repression increased with the procyanidin content of the extract and was observed not only to be species specific, but also strain specific. Interestingly, even if Lactobacillus and Bifidobacteria were likewise sensitive to the phenolic concentration and to the content of procyanidins, specific strains such as $L$. casei and $L$. plantarum were able to reach maximal growth with the three extracts. ${ }^{55}$ Viveros et al. ${ }^{56}$ analyzed and compared cecal and ileal digesta from broiler chicks treated with GSE and grape pomace concentrate (GPC) by plate count and Terminal restriction fragment lenght polymorphism (T-RFLP) method. The impact of both extracts on bacterial ecosystem of both regions was noticed to differ. Besides, T-RFLP approach made possible to confirm that major changes in treated groups were given in uncultured and unidentified species. ${ }^{56}$ Moreover, the combination of grape polyphenols with dietary fiber has been demonstrated to improve the desired prebiotic effect. This is the case of grape antioxidant dietary fiber (GADF), a natural product derived from red grapes that was demonstrated to boost Lactobacili 
growth, in rats $(50 \mathrm{~g} / \mathrm{kg})$ but also in vitro, whereby GADF was able to significantly increase the growth of L. acidophilus and L. reuteri. ${ }^{57}$ Extractable polyphenols (proanthocyanidins) are an important part of GADF, but there is also an important percentage $(14.8 \%)$ of non-extractable proanthocyanidins (NEPA), which have been demonstrated to be metabolized by intestinal microbiota. The confirmed interaction between grape derived proanthocyanidins and intestinal bacteria has, in turn, given rise to human studies whereby the prebiotic effects of proanthocyanidin-rich extract $(0.19$ $\mathrm{g} /$ day/subject) intake for 2 weeks, significantly increased the number of Bifidobacterium in healthy adults and tended to decrease the number of putrefactive bacteria, such as Enterobacteriaceae. $^{58}$

\section{Berries}

Berries contain abundant phenolic compounds, mostly flavonoids (where anthocyanins predominate). Some in vitro studies carried out with diverse berry extracts evaluated their antimicrobial activity on Gram-positive and Gram-negative bacteria. Interestingly, berry extracts inhibited Gram-negative bacteria, such as intestinal pathogen Salmonella enterica, but not Gram-positive beneficial probiotic lactic acid bacteria. ${ }^{59}$ Staphylococcus and Salmonella were the most sensitive, and the strongest inhibitory action was observed with cloudberry and raspberry, being this outcome largely attributed to their ellagitannin content (191 and $146 \mathrm{mg} / \mathrm{g}$, respectively). Importantly, the lower $\mathrm{pH}$ produced on the media was hypothesized as a possible explanation for the antimicrobial action, as it seems that low $\mathrm{pH}$ values promote the growth of probiotic bacteria, while pathogenic bacteria present high variability in their tolerance to acids. ${ }^{60}$ Wild blueberry (Vaccinum augustifolium) is characterized by its high content in anthocyanidins, whose prebiotic activity has been documented in vitro and in vivo. 
Thus, soluble extracts of two New Zealand blueberry cultivars promoted the growth of L. rhamnosus and B. breve in vitro and, more importantly, both extracts were demonstrated to effectively induce the growth of Lactobacilli and Bifidobacteria in the caecum of rats orally gavaged with these extracts $(4 \mathrm{~mL} / \mathrm{kg} /$ day $)$ for 6 days. ${ }^{61}$ Caecal contents of rats treated with supplements, whose major component was the blackcurrant extract powder, were also estimated using the Fluorescent in situ hybridization (FISH) technology. Rats administered the blackurrant aqueous extract presented a significant increase in bifidobacterial numbers and a significant decrease in bacteroides and clostridial numbers. ${ }^{62}$ In an intervention study with 15 healthy male individuals who underwent a dietary intervention where a wild blueberry drink was given before or after a placebo drink, a significant increase in Bifidobacterium spp. and Lactobacillus acidophilus group was also detected. ${ }^{63}$

\section{Conclusions}

This review has outlined some of the current work carried out facing the impact of polyphenols or polyphenol-rich dietary sources on gut microbial ecosystem evidencing an interaction between gut microbes and these compounds. When comparing results obtained from in vitro studies with data from in vivo experiments, no direct extrapolations could be made without a special mention to diverse factors acting up on this process.

\section{Type of in vitro experiments}

In this regard, the in vitro experiments discussed in this work have been performed by different approaches, such as in vitro traditional culture techniques or cultivation, in vitro faecal batch culture fermentation systems and Simulator of the Human Intestinal Microbial Ecosystem (SHIME). 


\section{Bacteria inoculation with individual polyphenols}

The simplest experiments where diverse bacteria species were inoculated with pure polyphenols have been useful to confirm that either flavonoids or non-flavonoids could produce an antimicrobial activity against pathogenic bacteria, ${ }^{16}$ but also a growth promoting effect for some beneficial commensal bacteria. ${ }^{26}$ Nevertheless, the biological relevance of these types of outcomes is uncertain, as polyphenols bioavailability is very low and they undergo an extensive modification within the organism. ${ }^{64}$ In this sense, special care should be taken as in vitro studies do not consider that some polyphenols are directly absorbed in the small intestine, while others reach the colon being degraded by microbiota to produce metabolites which, in some cases, could be more active than the original compounds. ${ }^{65}$ There are many review articles that elegantly explain polyphenols biotransformation in the gut, which is not the core of this work. ${ }^{15,66}$ Anyway, a basic concept such as the fact that the chemical structure of polyphenols largely influences their absorption and metabolism should be taken into account. In this sense, glycosides that reach the colon will be hydrolysed into aglycones by microflora and will subsequently suffer other structural modifications, such as methylation, sulfation and glucuronidation processes. ${ }^{64}$ This is relevant to understand some data from in vitro experiments, as for instance the work reported by Duda-Chodak et al. ${ }^{16}$, who concluded that aglycones (naringenin, quercetin and hesperetin) were powerful antibacterial compounds compared to their glycosides (naringin and rutin). Therefore, when trying to draw any conclusive statement about the biological effect of a certain polyphenol, the author's should be aware of the process of compounds' bioconversion, in order to avoid the use of erroneous polyphenols in their experiments. ${ }^{64}$ 
On the other hand, in these studies a limited number of bacterial species were inoculated, ignoring the bacterial complexity found in the intestine. In most cases, a limited number of strains from Lactobacillus, Bifidobacterium, Clostridium, Staphylococcus, Salmonella, Bacteroides and Escherichia genus ${ }^{16-18,26}$ were incubated with pure polyphenols. Hence, as not all bacterial strains could be evaluated in these assays, those microorganisms that have been proved to be responsible for the hydrolyzation of some of the tested compounds, as for instance Bacteroides uniformis and Bacteroides ovatus, obligate anaerobes that convert rutin to quercetin ${ }^{15}$ were left without being analyzed. Despite these types of experiments are considered the initial step for the posterior in vivo experiments, they are essential to gain knowledge for the succeeding human subject's classification on low, medium and high polyphenol metabolisers. This is the case of daidzein, a soy isoflavone, whose metabolism gives equol (whose biological properties might be beyond its precursors') when equolforming bacteria are present in the intestine. ${ }^{67}$ Knowledge about the conversion of the mentioned compound has allowed discerning a great variability between individuals regarding their ability to produce its metabolite, attributed to differences in their gut microbiota composition. ${ }^{68}$ This sort of information might be useful for personalized nutritional recommendations in the future. Anyway, there are other factors apart from the hosts` baseline gut microbiota composition, such as genetics and the metabolic state of the host that should be considered in order to be able to clarify the exact mechanisms contributing to the health benefits and to distinguish the direct correlation between bacterial strains and the metabolic products resulted from their interaction with polyphenols.

\section{Batch culture fermentation system}


In this regard, the use of batch culture fermentation systems has been also reported in this work. ${ }^{27}$ This approach, characterized to exhibit similar conditions to the human colonic region, aims to assess the effect of polyphenols ${ }^{27}$ or polyphenol-rich extracts $27,30,39,61$ on the growth of faecal bacteria population using human faecal slurries. Even if these systems are static models that aim to give information about colonic degradation of polyphenols and allow scientists to fix strict conditions regarding oxygen, temperature and $\mathrm{pH}$ of the medium, an important point to bear in mind is that faecal samples used might not entail the same characteristics of daily faecal production. Moreover, one of the main limitations when trying to address the gut microbial polyphenol metabolism in these types of assays is the interindividual variability. Faecal samples obtained from different individuals will exhibit distinct bacterial population for numerous reasons (i.e. diet, exercise, water, absorption/hydratation state, minor infections, stress and so on), thus they could present a variable metabolic capacity ${ }^{69}$ giving rise to different conclusions.

\section{Simulator of the Human Intestinal Microbial Ecosystem (SHIME)}

Another undeniable factor affecting results is the repercussion of the experiments' duration. In contrast to the aforementioned in vitro static systems, continuous multistaged culture systems that simulate the human microbial community in the large intestine have been developed. ${ }^{70}$ Studies carried out in SHIME models ${ }^{32,43}$ have allowed scientists to assess in vitro the implication of a two-week continuous treatment period with black tea, wine extract or a soygerm powder in colonic microbiota composition. As a matter of fact, even if this system is considered to better mimic the real polyphenolgut microbial interaction happening in the organism, it should be underlined that this approach takes for granted that the extracts reach intact to the colonic region, which is 
far from the reality. ${ }^{15}$ Moreover, owing to the high inter-relationship between host factors and the complex intestinal bacteria community, in vitro studies should be supported with further research in vivo and with human intervention trials to be able to elucidate the mechanisms underlying this interaction.

\section{In vivo studies and human intervention studies}

This review summarizes data from 16 studies conducted in animal models compared to 8 human intervention studies. It is widely known that preliminary evidences should be warranted in animal models before human intervention trials. In fact, they contribute to better understand the mechanisms and biological effects that could be likely to happen in human biology. Furthermore, a good design in human studies is indispensable in order to make as feasible as possible the conclusions drawn. In many cases it can be difficult to count on volunteers collaboration who meet the criteria and are ready to begin a relatively long-term study (4 to 10 weeks), so that the number of participants enrolled might be quite poor ( 8 subjects to 22 subjects). This might lead the researchers to sketch crossover studies ${ }^{30}$ in which participants are randomly subjected to a sequence of two or more treatments, and allow removing participants' variation, as well as being more efficient than trials performed in parallel with the same number of subjects. However, their principal disadvantage is that the effects of one treatment might "carryover" and modify the response to the following treatments. In fact, some trials

cited in the present work ${ }^{40}$ have skipped the wash out periods between treatments that might be key in order to favour the continuation of the study by the participants.

\section{Quantification techniques}

The final technique used for the bacteria identification and quantification is of great relevance. It is widely known that $60-80 \%$ of bacterial species have been reported to be 
non-cultivable by culture-dependent methods. Thus, these approaches failed to identify a large fraction of gut microbial diversity. Interestingly, at present, the advances gained in molecular techniques have made possible to overcome limitations of culture dependent methods ${ }^{71}$ being able to give a more representative view of all bacterial community in the gut. Nevertheless, these techniques should be complementary, and ideally an inter-disciplinary approach comprising several "omics" approaches without the exclusion of culture-dependent techniques should be conducted. An example of this combination could be found in an experiment performed by Kemperman et al. ${ }^{32}$, where data obtained from different microbiological analyses (cultivation, qPCR, PCR-DGGE and $16 \mathrm{~S}$ rRNA pyrosequencing) were compared and the previously mentioned limitations of traditional culture techniques became visible. The culture-dependent technique used in this experiment estimated a lower bacterial number and was not able to detect conclusive antimicrobial effect of the extracts tested, whereas the aforementioned techniques were able to distinguish different bacterial clusters depending on the tested compounds. ${ }^{32}$ In general, from the articles cited in this review, it could be suggested that culture-dependent techniques were mainly focused on the identification/quantification of six genus (Lactobacillus, Bifidobacterium, Escherichia, Salmonella, Staphylococcus and Bacillus) belonging to one of three major classes (Firmicutes, Proteobacteria, Actinobacteria), ${ }^{31,33-35,57,61}$ while those studies performed with accurate and powerful molecular techniques, such as 16S rRNA pyrosequencing, FISH, FISH-FCM and PCR-DGGE, enabled the characterization of genus (Victivallis, Akkermansia) from not so abundant phyla (Chlyamydiae/Verrucomicrobia group) and conduct an in-depth characterization of bacterial populations at species levels. However, briefly, it could be said that even a lot of progress has been made in the last years in the area of gut microbiota, still some challenges regarding parameters such as sampling, the 
sequencing depth and setting the limits of the regions to be analyzed remain to be agreed so that experiments could be completely reproducible. The advances in sequencing technology will permit to detect all the bacterial species and strains, at a level of detail much more precise than the previously used techniques.

\section{Final remarks}

From a health perspective, the intake of phenolic compounds, either as pure compounds or as part of food constituents, could be an effective approach to modulate gut microbiota, enhancing the growth of specific beneficial bacteria strains, while competitively excluding specific pathogenic bacteria. However, further research is needed, especially in humans, to elucidate the specific effects of phenolic compounds on the growth of different gut bacteria, their interactions with other polyphenols and dietary components, the individual genetic, inflammatory and microbiota background, as well as the involvement of polyphenol-microbiota interactions on the beneficial effects attributed to polyphenols on different chronic diseases.

\section{ABBREVIATIONS USED}

NO, nitric oxide; MIC, minimum inhibitory concentration; Clostridium coccoidesEubacterium rectale, Erec; $\mathrm{IC}_{50}$, half maximal inhibitory concentration; BMI, body mass index; LCF, low-cocoa flavanol; HCF, high-cocoa flavanol; CRP, c-reactive protein; GTE, green tea extract; GT, green tea powder; Lp, Lactobacillus plantarum DSM 15313; RW, red wine; DRW, de-alcoholized red wine; SHIME, Simulator of the Human Intestinal Microbial Ecosystem; PPE, pomegranate peel extract; GSE, grape seed extract; GSE-M, monomeric-rich fraction of grape seed extract; GSE-O, oligomeric-rich fraction of grape seed extract; GPC, grape pomace concentrate; T-RFLP, Terminal 
Restriction Fragment Length Polymorphism; GADF, grape antioxidant dietary fiber;

NEPA, non-extractable proanthocyanidins; FISH, Fluorescent in situ hybridization.

\section{References}

(1) Del Rio, D.; Rodriguez-Mateos, A.; Spencer, J. P.; Tognolini, M.; Borges, G.; Crozier, A. Dietary (poly)phenolics in human health: structures, bioavailability, and evidence of protective effects against chronic diseases. Antioxid Redox Signal. 2013, 18, 1818-1892.

(2) Landete, J. M. Updated knowledge about polyphenols: functions, bioavailability, metabolism, and health. Crit Rev Food Sci Nutr. 2012, 52, 936-948.

(3) Chiva-Blanch, G.; Visioli, F. Polyphenols and health: Moving beyond antioxidants. Journal of Berry Research. 2012, 2, 63-71.

(4) Hervert-Hernández, D.; Goñi, I. Dietary Polyphenols and Human Gut Microbiota: a Review. Food Reviews International. 2011, 27, 154-169.

(5) Bolca, S.; Van de Wiele, T.; Possemiers, S. Gut metabotypes govern health effects of dietary polyphenols. Curr Opin Biotechnol. 2013, 24, 220-225.

(6) O'Hara, A. M.; Shanahan, F. The gut flora as a forgotten organ. EMBO Rep. 2006, 7, 688693.

(7) Beaugerie, L.; Petit, J. C. Microbial-gut interactions in health and disease. Antibioticassociated diarrhoea. Best Pract Res Clin Gastroenterol. 2004, 18, 337-352.

(8) Flint, H. J. The impact of nutrition on the human microbiome. Nutr Rev. 2012, 70 Suppl 1, S10-13.

(9) De Filippo, C.; Cavalieri, D.; Di Paola, M.; Ramazzotti, M.; Poullet, J. B.; Massart, S.; Collini, S.; Pieraccini, G.; Lionetti, P. Impact of diet in shaping gut microbiota revealed by a comparative study in children from Europe and rural Africa. Proc Natl Acad Sci U S A. 2010, 107, 14691-14696.

(10) Yatsunenko, T.; Rey, F. E.; Manary, M. J.; Trehan, I.; Dominguez-Bello, M. G.; Contreras, M.; Magris, M.; Hidalgo, G.; Baldassano, R. N.; Anokhin, A. P.; Heath, A. C.; Warner, B.; Reeder, J.; Kuczynski, J.; Caporaso, J. G.; Lozupone, C. A.; Lauber, C.; Clemente, J. C.; Knights, D.; Knight, R.; Gordon, J. I. Human gut microbiome viewed across age and geography. Nature. 2012, 486, 222-227.

(11) Duncan, S. H.; Louis, P.; Thomson, J. M.; Flint, H. J. The role of $\mathrm{pH}$ in determining the species composition of the human colonic microbiota. Environ Microbiol. 2009, 11, 2112-2122.

(12) Duncan, S. H.; Belenguer, A.; Holtrop, G.; Johnstone, A. M.; Flint, H. J.; Lobley, G. E. Reduced dietary intake of carbohydrates by obese subjects results in decreased concentrations of butyrate and butyrate-producing bacteria in feces. Appl Environ Microbiol. 2007, 73, 10731078.

(13) Nicholson, J. K.; Holmes, E.; Kinross, J.; Burcelin, R.; Gibson, G.; Jia, W.; Pettersson, S. Hostgut microbiota metabolic interactions. Science. 2012, 336, 1262-1267. 
(14) Tuohy, K. M.; Conterno, L.; Gasperotti, M.; Viola, R. Up-regulating the human intestinal microbiome using whole plant foods, polyphenols, and/or fiber. J Agric Food Chem. 2012, 60, 8776-8782.

(15) Selma, M. V.; Espin, J. C.; Tomas-Barberan, F. A. Interaction between phenolics and gut microbiota: role in human health. J Agric Food Chem. 2009, 57, 6485-6501.

(16) Duda-Chodak, A. The inhibitory effect of polyphenols on human gut microbiota. J Physiol Pharmacol. 2012, 63, 497-503.

(17) Kawabata, K.; Sugiyama, Y.; Sakano, T.; Ohigashi, H. Flavonols enhanced production of anti-inflammatory substance(s) by Bifidobacterium adolescentis: Prebiotic actions of galangin, quercetin, and fisetin. Biofactors. 2013.

(18) Parkar, S. G.; Stevenson, D. E.; Skinner, M. A. The potential influence of fruit polyphenols on colonic microflora and human gut health. Int J Food Microbiol. 2008, 124, 295-298.

(19) Tzounis, X.; Vulevic, J.; Kuhnle, G. G.; George, T.; Leonczak, J.; Gibson, G. R.; Kwik-Uribe, C.; Spencer, J. P. Flavanol monomer-induced changes to the human faecal microflora. Br J Nutr. 2008, 99, 782-792.

(20) Hara, Y. Influence of tea catechins on the digestive tract. J Cell Biochem Suppl. 1997, 27, 52-58.

(21) Lee, H. C.; Jenner, A. M.; Low, C. S.; Lee, Y. K. Effect of tea phenolics and their aromatic fecal bacterial metabolites on intestinal microbiota. Res Microbiol. 2006, 157, 876-884.

(22) Clavel, T.; Fallani, M.; Lepage, P.; Levenez, F.; Mathey, J.; Rochet, V.; Serezat, M.; Sutren, M.; Henderson, G.; Bennetau-Pelissero, C.; Tondu, F.; Blaut, M.; Dore, J.; Coxam, V. Isoflavones and functional foods alter the dominant intestinal microbiota in postmenopausal women. $J$ Nutr. 2005, 135, 2786-2792.

(23) Smith, A. H.; Mackie, R. I. Effect of condensed tannins on bacterial diversity and metabolic activity in the rat gastrointestinal tract. Appl Environ Microbiol. 2004, 70, 1104-1115.

(24) Larrosa, M.; Yanez-Gascon, M. J.; Selma, M. V.; Gonzalez-Sarrias, A.; Toti, S.; Ceron, J. J.; Tomas-Barberan, F.; Dolara, P.; Espin, J. C. Effect of a low dose of dietary resveratrol on colon microbiota, inflammation and tissue damage in a DSS-induced colitis rat model. J Agric Food Chem. 2009, 57, 2211-2220.

(25) Espin, J. C.; Larrosa, M.; Garcia-Conesa, M. T.; Tomas-Barberan, F. Biological significance of urolithins, the gut microbial ellagic Acid-derived metabolites: the evidence so far. Evid Based Complement Alternat Med. 2013, 2013, 270418.

(26) Bialonska, D.; Kasimsetty, S. G.; Schrader, K. K.; Ferreira, D. The effect of pomegranate (Punica granatum L.) byproducts and ellagitannins on the growth of human gut bacteria. $J$ Agric Food Chem. 2009, 57, 8344-8349.

(27) Bialonska, D.; Ramnani, P.; Kasimsetty, S. G.; Muntha, K. R.; Gibson, G. R.; Ferreira, D. The influence of pomegranate by-product and punicalagins on selected groups of human intestinal microbiota. Int J Food Microbiol. 2010, 140, 175-182. 
(28) Reddy, M. K.; Gupta, S. K.; Jacob, M. R.; Khan, S. I.; Ferreira, D. Antioxidant, antimalarial and antimicrobial activities of tannin-rich fractions, ellagitannins and phenolic acids from Punica granatum L. Planta Med. 2007, 73, 461-467.

(29) Massot-Cladera, M.; Perez-Berezo, T.; Franch, A.; Castell, M.; Perez-Cano, F. J. Cocoa modulatory effect on rat faecal microbiota and colonic crosstalk. Arch Biochem Biophys. 2012, $527,105-112$.

(30) Tzounis, X.; Rodriguez-Mateos, A.; Vulevic, J.; Gibson, G. R.; Kwik-Uribe, C.; Spencer, J. P. Prebiotic evaluation of cocoa-derived flavanols in healthy humans by using a randomized, controlled, double-blind, crossover intervention study. Am J Clin Nutr. 2011, 93, 62-72.

(31) Ahn, Y.-J.; Sakanaka, S.; Kim, M.-J.; Kawamura, T.; Fujisawa, T.; Mitsuoka, T. Effect of Green Tea Extract on Growth of Intestinal Bacteria. Microbial Ecology in Health and Disease. 1990, 3, 335-338.

(32) Kemperman, R. A.; Gross, G.; Mondot, S.; Possemiers, S.; Marzorati, M.; Van de Wiele, T.; Doré, J.; Vaughan, E. E. Impact of polyphenols from black tea and red wine/grape juice on a gut model microbiome. Food Research International. 2013. http://dx.doi.org/10.1016/j.foodres.2013.01.034.

(33) Hara, H.; Orita, N.; Hatano, S.; Ichikawa, H.; Hara, Y.; Matsumoto, N.; Kimura, Y.; Terada, A.; Mitsuoka, T. Effect of tea polyphenols on fecal flora and fecal metabolic products of pigs. $J$ Vet Med Sci. 1995, 57, 45-49.

(34) Ishihara, N.; Chu, D. C.; Akachi, S.; Juneja, L. R. Improvement of intestinal microflora balance and prevention of digestive and respiratory organ diseases in calves by green tea extracts. Livestock Production Science. 2001, 68, 217-229.

(35) Okubo, T.; Ishihara, N.; Oura, A.; Serit, M.; Kim, M.; Yamamoto, T.; Mitsuoka, T. In Vivo Effects of Tea Polyphenol Intake on Human Intestinal Microflora and Metabolism. Bioscience, Biotechnology, and Biochemistry. 1992, 56, 588-591.

(36) Jin, J. S.; Touyama, M.; Hisada, T.; Benno, Y. Effects of green tea consumption on human fecal microbiota with special reference to Bifidobacterium species. Microbiol Immunol. 2012, 56, 729-739.

(37) Axling, U.; Olsson, C.; Xu, J.; Fernandez, C.; Larsson, S.; Strom, K.; Ahrne, S.; Holm, C.; Molin, G.; Berger, K. Green tea powder and Lactobacillus plantarum affect gut microbiota, lipid metabolism and inflammation in high-fat fed C57BL/6J mice. Nutr Metab (Lond). 2012, 9, 105.

(38) Dolara, P.; Luceri, C.; De Filippo, C.; Femia, A. P.; Giovannelli, L.; Caderni, G.; Cecchini, C.; Silvi, S.; Orpianesi, C.; Cresci, A. Red wine polyphenols influence carcinogenesis, intestinal microflora, oxidative damage and gene expression profiles of colonic mucosa in F344 rats. Mutat Res. 2005, 591, 237-246.

(39) Sanchez-Patan, F.; Cueva, C.; Monagas, M.; Walton, G. E.; Gibson, G. R.; Quintanilla-Lopez, J. E.; Lebron-Aguilar, R.; Martin-Alvarez, P. J.; Moreno-Arribas, M. V.; Bartolome, B. In vitro fermentation of a red wine extract by human gut microbiota: changes in microbial groups and formation of phenolic metabolites. J Agric Food Chem. 2012, 60, 2136-2147. 
(40) Queipo-Ortuno, M. I.; Boto-Ordonez, M.; Murri, M.; Gomez-Zumaquero, J. M.; ClementePostigo, M.; Estruch, R.; Cardona Diaz, F.; Andres-Lacueva, C.; Tinahones, F. J. Influence of red wine polyphenols and ethanol on the gut microbiota ecology and biochemical biomarkers. Am J Clin Nutr. 2012, 95, 1323-1334.

(41) Fernandez-Raudales, D.; Hoeflinger, J. L.; Bringe, N. A.; Cox, S. B.; Dowd, S. E.; Miller, M. J.; Gonzalez de Mejia, E. Consumption of different soymilk formulations differentially affects the gut microbiomes of overweight and obese men. Gut Microbes. 2012, 3, 490-500.

(42) Piacentini, G.; Peroni, D.; Bessi, E.; Morelli, L. Molecular characterization of intestinal microbiota in infants fed with soymilk. J Pediatr Gastroenterol Nutr. 2010, 51, 71-76.

(43) De Boever, P.; Deplancke, B.; Verstraete, W. Fermentation by gut microbiota cultured in a simulator of the human intestinal microbial ecosystem is improved by supplementing a soygerm powder. J Nutr. 2000, 130, 2599-2606.

(44) Bedani, R.; Pauly-Silveira, N. D.; Roselino, M. N.; de Valdez, G. F.; Rossi, E. A. Effect of fermented soy product on the fecal microbiota of rats fed on a beef-based animal diet. J Sci Food Agric. 2010, 90, 233-238.

(45) Cavallini, D. C.; Suzuki, J. Y.; Abdalla, D. S.; Vendramini, R. C.; Pauly-Silveira, N. D.; Roselino, M. N.; Pinto, R. A.; Rossi, E. A. Influence of a probiotic soy product on fecal microbiota and its association with cardiovascular risk factors in an animal model. Lipids Health Dis. 2011, 10, 126.

(46) Larrosa, M.; Gonzalez-Sarrias, A.; Yanez-Gascon, M. J.; Selma, M. V.; Azorin-Ortuno, M.; Toti, S.; Tomas-Barberan, F.; Dolara, P.; Espin, J. C. Anti-inflammatory properties of a pomegranate extract and its metabolite urolithin-A in a colitis rat model and the effect of colon inflammation on phenolic metabolism. J Nutr Biochem. 2010, 21, 717-725.

(47) Neyrinck, A. M.; Van Hee, V. F.; Bindels, L. B.; De Backer, F.; Cani, P. D.; Delzenne, N. M. Polyphenol-rich extract of pomegranate peel alleviates tissue inflammation and hypercholesterolaemia in high-fat diet-induced obese mice: potential implication of the gut microbiota. Br J Nutr. 2013, 109, 802-809.

(48) Licht, T. R.; Hansen, M.; Bergstrom, A.; Poulsen, M.; Krath, B. N.; Markowski, J.; Dragsted, L. O.; Wilcks, A. Effects of apples and specific apple components on the cecal environment of conventional rats: role of apple pectin. BMC Microbiol. 2010, 10, 13.

(49) Sembries, S.; Dongowski, G.; Mehrlander, K.; Will, F.; Dietrich, H. Physiological effects of extraction juices from apple, grape, and red beet pomaces in rats. J Agric Food Chem. 2006, 54, 10269-10280.

(50) Sembries, S.; Dongowski, G.; Jacobasch, G.; Mehrlander, K.; Will, F.; Dietrich, H. Effects of dietary fibre-rich juice colloids from apple pomace extraction juices on intestinal fermentation products and microbiota in rats. Br J Nutr. 2003, 90, 607-615.

(51) Aprikian, O.; Duclos, V.; Guyot, S.; Besson, C.; Manach, C.; Bernalier, A.; Morand, C.; Remesy, C.; Demigne, C. Apple pectin and a polyphenol-rich apple concentrate are more effective together than separately on cecal fermentations and plasma lipids in rats. $J$ Nutr. 2003, 133, 1860-1865. 
(52) Cueva, C.; Sanchez-Patan, F.; Monagas, M.; Walton, G. E.; Gibson, G. R.; Martin-Alvarez, P. J.; Bartolome, B.; Moreno-Arribas, M. V. In vitro fermentation of grape seed flavan-3-ol fractions by human faecal microbiota: changes in microbial groups and phenolic metabolites. FEMS Microbiol Ecol. 2013, 83, 792-805.

(53) Mayer, R.; Stecher, G.; Wuerzner, R.; Silva, R. C.; Sultana, T.; Trojer, L.; Feuerstein, I.; Krieg, C.; Abel, G.; Popp, M.; Bobleter, O.; Bonn, G. K. Proanthocyanidins: target compounds as antibacterial agents. J Agric Food Chem. 2008, 56, 6959-6966.

(54) Baydar, N. G.; Ozkan, G.; Sagdic, O. Total phenolic contents and antibacterial activities of grape (Vitis vinifera L.) extracts. Food Control. 2004, 15, 335-339.

(55) Tabasco, R.; Sanchez-Patan, F.; Monagas, M.; Bartolome, B.; Victoria Moreno-Arribas, M.; Pelaez, C.; Requena, T. Effect of grape polyphenols on lactic acid bacteria and bifidobacteria growth: resistance and metabolism. Food Microbiol. 2011, 28, 1345-1352.

(56) Viveros, A.; Chamorro, S.; Pizarro, M.; Arija, I.; Centeno, C.; Brenes, A. Effects of dietary polyphenol-rich grape products on intestinal microflora and gut morphology in broiler chicks. Poult Sci. 2011, 90, 566-578.

(57) Pozuelo, M. J.; Agis-Torres, A.; Hervert-Hernandez, D.; Elvira Lopez-Oliva, M.; MunozMartinez, E.; Rotger, R.; Goni, I. Grape antioxidant dietary fiber stimulates Lactobacillus growth in rat cecum. J Food Sci. 2012, 77, H59-62.

(58) Yamakoshi, J.; Tokutake, S.; Kikuchi, M.; Kubota, Y.; Konishi, H.; Mitsuoka, T. Effect of proanthocyanidin-rich extract from grape seeds on human fecal fora and fecal odor. Faseb Journal. 2001, 15, A633-A633.

(59) Puupponen-Pimia, R.; Nohynek, L.; Meier, C.; Kahkonen, M.; Heinonen, M.; Hopia, A.; Oksman-Caldentey, K. M. Antimicrobial properties of phenolic compounds from berries. J Appl Microbiol. 2001, 90, 494-507.

(60) Puupponen-Pimia, R.; Nohynek, L.; Hartmann-Schmidlin, S.; Kahkonen, M.; Heinonen, M.; Maatta-Riihinen, K.; Oksman-Caldentey, K. M. Berry phenolics selectively inhibit the growth of intestinal pathogens. J Appl Microbiol. 2005, 98, 991-1000.

(61) Molan, A.; Lila, M.; Mawson, J.; De, S. In vitro and in vivo evaluation of the prebiotic activity of water-soluble blueberry extracts. World Journal of Microbiology and Biotechnology. 2009, 25, 1243-1249.

(62) Molan, A.-L.; Liu, Z.; Kruger, M. The ability of blackcurrant extracts to positively modulate key markers of gastrointestinal function in rats. World Journal of Microbiology and Biotechnology. 2010, 26, 1735-1743.

(63) Vendrame, S.; Guglielmetti, S.; Riso, P.; Arioli, S.; Klimis-Zacas, D.; Porrini, M. Six-week consumption of a wild blueberry powder drink increases bifidobacteria in the human gut. $J$ Agric Food Chem. 2011, 59, 12815-12820.

(64) D'Archivio, M.; Filesi, C.; Vari, R.; Scazzocchio, B.; Masella, R. Bioavailability of the polyphenols: status and controversies. Int J Mol Sci. 2010, 11, 1321-1342. 
(65) Setchell, K. D.; Brown, N. M.; Lydeking-Olsen, E. The clinical importance of the metabolite equol-a clue to the effectiveness of soy and its isoflavones. J Nutr. 2002, 132, 3577-3584.

(66) Moco, S.; Martin, F. P.; Rezzi, S. Metabolomics view on gut microbiome modulation by polyphenol-rich foods. J Proteome Res. 2012, 11, 4781-4790.

(67) Magee, P. J. Is equol production beneficial to health? Proc Nutr Soc. 2011, 70, 10-18.

(68) Rafii, F.; Davis, C.; Park, M.; Heinze, T. M.; Beger, R. D. Variations in metabolism of the soy isoflavonoid daidzein by human intestinal microfloras from different individuals. Arch Microbiol. 2003, 180, 11-16.

(69) van Duynhoven, J.; Vaughan, E. E.; Jacobs, D. M.; Kemperman, R. A.; van Velzen, E. J.; Gross, G.; Roger, L. C.; Possemiers, S.; Smilde, A. K.; Dore, J.; Westerhuis, J. A.; Van de Wiele, T. Metabolic fate of polyphenols in the human superorganism. Proc Natl Acad Sci U S A. 2011, 108 Suppl 1, 4531-4538.

(70) Molly, K.; Vande Woestyne, M.; Verstraete, W. Development of a 5-step multi-chamber reactor as a simulation of the human intestinal microbial ecosystem. Appl Microbiol Biotechnol. 1993, 39, 254-258.

(71) Andoh, A.; Benno, Y.; Kanauchi, O.; Fujiyama, Y. Recent advances in molecular approaches to gut microbiota in inflammatory bowel disease. Curr Pharm Des. 2009, 15, 2066-2073.

Notes: This study was supported by grants from Instituto de Salud Carlos III (PREDIMED, CIBERobn), Government of the Basque Country (IT-512-13), University of the Basque Country (UPV/EHU) (ELDUNANOTEK, UFI11/32) and Línea Especial from University of Navarra (Spain). The authors wish to thank the Department of Education, Universities and Research of Basque Government for the predoctoral grant given to Usune Etxeberria. 
Table 1. Polyphenolic-rich Beverages (Cocoa, Tea, Wine) With Potential Effects On Gut Microbiota Composition

\begin{tabular}{|c|c|c|c|c|c|c|c|}
\hline $\begin{array}{l}\text { Food or food } \\
\text { extracts rich in } \\
\text { polyphenols }\end{array}$ & $\begin{array}{l}\text { Type of } \\
\text { study }\end{array}$ & Duration & Dosis & $\begin{array}{c}\text { Techniques } \\
\text { used }\end{array}$ & $\begin{array}{c}\text { Antimicrobial activity } \\
\text { (AMA) }\end{array}$ & $\begin{array}{c}\text { Bacteria growth } \\
\text { promoting effect (BGPE) }\end{array}$ & Reference \\
\hline Cocoa & Animal study & 6 weeks & $\begin{array}{c}10 \%(\mathrm{w} / \mathrm{w}) \\
(10.62 \mathrm{mg} / \mathrm{g} \text { polyphenols })\end{array}$ & FISH-FCM $^{\mathrm{a}}$ & $\begin{array}{l}\text { - Bacteroides genus } \\
\text { - Clostridium genus } \\
\text { - Staphylococcus genus }\end{array}$ & & 29 \\
\hline \multirow[t]{3}{*}{ Cocoa drink } & $\begin{array}{c}\text { Human } \\
\text { intervention }\end{array}$ & 4 weeks & $\begin{array}{c}\mathrm{HCF}^{\mathrm{b}} \\
\text { (494 mg cocoa flavanols) }\end{array}$ & FISH & - Clostridium histolyticum group & $\begin{array}{l}\text { - Eubacterium rectale- } \\
\quad \text { C. coccoides group } \\
\text { - Lactobacillus spp. } \\
\text { - Enterococcus spp } \\
\text { - Bifidobacterium spp. }\end{array}$ & \\
\hline & & & $\begin{array}{c}\mathrm{LCF}^{\mathrm{c}} \\
(29 \mathrm{mg} \text { cocoa flavanols })\end{array}$ & & & $\begin{array}{l}\text { - Eubacterium rectale- } \\
\text { C. coccoides group } \\
\text { - Clostridium histolyticum group } \\
\text { - Lactobacillus spp. } \\
\text { - Enterococcus spp. }\end{array}$ & 30 \\
\hline & In vitro study & $\begin{array}{c}6 \mathrm{~h} \\
\text { incubation }\end{array}$ & $\begin{array}{l}\text { High-flavanol cocoa-powder } \\
\text { extract } \\
(1 \mathrm{mg} / \mathrm{mL} ; 0.4 \mathrm{mg} / \mathrm{mL} \\
\text { flavanols })\end{array}$ & $\begin{array}{c}\text { Batch } \\
\text { culture } \\
\text { fermentation } \\
\text { model }\end{array}$ & - Clostridium histolyticum group & $\begin{array}{l}\text {-Lactobacillus spp. } \\
\text {-Bifidobacterium spp. }\end{array}$ & \\
\hline $\begin{array}{c}\text { Black tea } \\
\text { extract }\end{array}$ & In vitro study & 2 weeks & $1000 \mathrm{mg} /$ day & $\begin{array}{l}\text { SHIME }^{\mathrm{d}} \text { and } \\
\mathrm{qPCR}^{\mathrm{e}} / \\
\text { Pyrosequenc } \\
\text { ing }\end{array}$ & $\begin{array}{l}\text { - Bifidobacteria } \\
\text { - Blautia coccoides } \\
\text { - Anaeroglobus } \\
\text { - Victivallis }\end{array}$ & $\begin{array}{l}\text { - Klebsiella sp. } \\
\text { - Enterococci } \\
\text { - Akkermansia }\end{array}$ & 32 \\
\hline $\begin{array}{c}\text { Tea } \\
\text { polyphenols }\end{array}$ & $\begin{array}{c}\text { Human } \\
\text { intervention }\end{array}$ & 4 weeks & $\begin{array}{c}\text { Suphenon }{ }^{\circledR} \\
(0.4 \mathrm{~g} / 3 \text { times per day })\end{array}$ & Plate count & $\begin{array}{l}\text { - Clostridium spp. } \\
\text { - Clostridium perfringens }\end{array}$ & - Bifidobacterium spp & 35 \\
\hline
\end{tabular}




\begin{tabular}{|c|c|c|c|c|c|c|c|}
\hline $\begin{array}{l}\text { Food or food } \\
\text { extracts rich in } \\
\text { polyphenols }\end{array}$ & $\begin{array}{l}\text { Type of } \\
\text { study }\end{array}$ & Duration & Dosis & $\begin{array}{c}\text { Techniques } \\
\text { used }\end{array}$ & $\begin{array}{l}\text { Antimicrobial activity } \\
\text { (AMA) }\end{array}$ & $\begin{array}{c}\text { Bacteria growth promoting } \\
\text { effect (BGPE) }\end{array}$ & Reference \\
\hline $\begin{array}{c}\text { Green tea } \\
\text { extract }\end{array}$ & In vitro study & $\begin{array}{c}2 \text { days } \\
\text { incubation }\end{array}$ & $10 \mathrm{mg}$ extract/disc & Plate count & $\begin{array}{l}\text { - Clostridium difficile ATCC } \\
9689 \\
\text { - Clostridium perfringens ATCC } \\
13124 \\
\text { - Clostridium perfringens B-3-7 } \\
\text { - Clostridum perfringens B-3-8 } \\
\text { - Clostridium perfringens B-165- } \\
16 \\
\text { - Clostridium perfringens C-01 } \\
\text { - Clostridium paraputrificum B- } \\
3-4 \\
\text { - Clostridium paraputrificum B- } \\
78 \\
\text { - Clostridium paraputrificum } \\
\text { VPI-6372 }\end{array}$ & & 31 \\
\hline $\begin{array}{c}\text { Tea } \\
\text { polyphenols }\end{array}$ & Animal study & 2 weeks & $0.2 \%$ tea polyphenols & Plate count & - Bacteroidaceae & - Lactobacilli & 33 \\
\hline $\begin{array}{c}\text { Green tea } \\
\text { leaves powder }\end{array}$ & Animal study & $\begin{array}{l}11 \text { and } 22 \\
\text { weeks }\end{array}$ & $\begin{array}{c}4 \% \mathrm{w} / \mathrm{w} \text { of } \mathrm{GT}^{\mathrm{f}}+ \\
\text { Lactobacillus plantarum } \\
\text { DSM } 15313\end{array}$ & $\begin{array}{l}\text { qPCR and } \\
\text { T-RFLP }\end{array}$ & & - Lactobacillus & 37 \\
\hline Green tea & $\begin{array}{l}\text { Human } \\
\text { intervention }\end{array}$ & 10 days & $1000 \mathrm{~mL} /$ day & $\begin{array}{l}\text { qPCR and } \\
\text { T-RFLP }\end{array}$ & & - Bifidobacterium spp. & 36 \\
\hline
\end{tabular}


Table 1. Continued

Food or food

Food or food
extracts rich in

Type of
study

Green Tea

In vitro study

Duration

Dosis

Techniques

Antimicrobial activity
(AMA)

Bacteria growth

2- 3 days

GTE- $1^{\mathrm{h}}$

used

promoting effect (BGPE)

Reference

Agar plate - Staphylococcus aureus I-001

dilution $\quad(125 \mu \mathrm{g} / \mathrm{mL})$

method - Staphylococcus epidermis

KK108

$(125 \mu \mathrm{g} / \mathrm{mL})$

- Streptococcus spp. K003 (200

$\mu \mathrm{g} / \mathrm{mL}$ )

- Corynebacterium suis 54001

$$
(750 \mu \mathrm{g} / \mathrm{mL})
$$

- Escherichia coli KK88 MN1

$$
(400 \mu \mathrm{g} / \mathrm{mL})
$$

- Escherichia coli KK88 G1253

$$
(400 \mu \mathrm{g} / \mathrm{mL})
$$

- Salmonella spp. O4 type K-011

$$
(200 \mu \mathrm{g} / \mathrm{mL})
$$

GTE-2

(>80\% polyphenols)
- Staphylococcus aureus KK101

$$
(50 \mu \mathrm{g} / \mathrm{mL})
$$

- Staphylococcus epidermis

$\mathrm{KK} 108(50 \mu \mathrm{g} / \mathrm{mL})$

- Streptococcus uberis KK204

$(200 \mu \mathrm{g} / \mathrm{mL})$

- Salmonella dublin L-729 (200

$$
\mu \mathrm{g} / \mathrm{mL} \text { ) }
$$

- Salmonella enteriditis L-58

$$
(200 \mu \mathrm{g} / \mathrm{mL})
$$

- Salmonella infantis L-164 (200 $\mu \mathrm{g} / \mathrm{mL}$ )

- Salmonella mbandaka L-743

$$
(200 \mu \mathrm{g} / \mathrm{mL})
$$

- Salmonella sofia L-59 (200 $\mu \mathrm{g} / \mathrm{mL}$ )

- Salmonella typhimurium L-413 $(200 \mu \mathrm{g} / \mathrm{mL})$ 
Table 1. Continued

\begin{tabular}{|c|c|c|c|c|c|c|c|}
\hline $\begin{array}{l}\text { Food or food } \\
\text { extracts rich in } \\
\text { polyphenols }\end{array}$ & $\begin{array}{l}\text { Type of } \\
\text { study }\end{array}$ & Duration & Dosis & $\begin{array}{l}\text { Techniques } \\
\text { used }\end{array}$ & $\begin{array}{c}\text { Antimicrobial activity } \\
\text { (AMA) }\end{array}$ & $\begin{array}{c}\text { Bacteria growth } \\
\text { promoting effect (BGPE) }\end{array}$ & Reference \\
\hline & Animal study & 4 weeks & $\begin{array}{c}\text { GTE-1 } \\
\text { (>60\% polyphenols) } \\
\text { GTE-2 } \\
\text { (>80\% polyphenols) }\end{array}$ & $\begin{array}{l}\text { Counting on } \\
\text { culture } \\
\text { medium }\end{array}$ & - Clostridium perfringens & \multirow[t]{2}{*}{$\begin{array}{l}\text { - Bifidobacterium spp. } \\
\text { - Lactobacillus spp. }\end{array}$} & 34 \\
\hline $\begin{array}{l}\text { Wine phenolic } \\
\text { extract }\end{array}$ & In vitro study & $\begin{array}{c}48 \mathrm{~h} \\
\text { incubation }\end{array}$ & $600 \mathrm{mg}$ wine extract & $\begin{array}{c}\text { Batch } \\
\text { culture } \\
\text { fermentation } \\
\text { model/ } \\
\text { FISH }\end{array}$ & - Clostridium histolyticum group & & 39 \\
\hline \multirow[t]{2}{*}{$\begin{array}{c}\text { Wine } \\
\text { polyphenols }\end{array}$} & \multirow[t]{2}{*}{$\begin{array}{l}\text { Human } \\
\text { intervention }\end{array}$} & \multirow[t]{2}{*}{4 weeks } & $\begin{array}{l}\text { De-alcoholized red wine } \\
\quad(272 \mathrm{~mL} / \text { day })\end{array}$ & $\begin{array}{l}\text { PCR- } \\
\text { DGGE }^{\mathrm{i}}\end{array}$ & \multirow[t]{2}{*}{$\begin{array}{l}\text { - Bacteroidetes } \\
\text { - Firmicutes }\end{array}$} & $\begin{array}{l}\text { - Fusobacteria } \\
\text { - Enterococcus genus } \\
\text { - Blautia coccoides- } \\
\quad \text { Eubacterium rectale } \\
\text { - Bifidobacterium } \\
\text { - Eggerthella lenta }\end{array}$ & \\
\hline & & & Red wine (272 mL/day) & & & $\begin{array}{l}\text { - Proteobacteria } \\
\text { - Prevotella } \\
\text { - Bifidobacterium } \\
\text { - Eggerthella lenta } \\
\text { - Fusobacteria } \\
\text { - Firmicutes } \\
\text { - Bacteroidetes } \\
\text { - Enterococcus genus } \\
\text { - Blautia coccoides- } \\
\quad \text { Eubacterium rectale } \\
\text { - Bacteroides genus } \\
\text { - Bacteroides uniformis sp. }\end{array}$ & 40 \\
\hline
\end{tabular}


Table 1. Continued

\begin{tabular}{|c|c|c|c|c|c|c|c|}
\hline $\begin{array}{l}\text { Food or food } \\
\text { extracts rich in } \\
\text { polyphenols }\end{array}$ & $\begin{array}{l}\text { Type of } \\
\text { study }\end{array}$ & Duration & Dosis & $\begin{array}{c}\text { Techniques } \\
\text { used }\end{array}$ & $\begin{array}{c}\text { Antimicrobial activity } \\
\text { (AMA) }\end{array}$ & $\begin{array}{c}\text { Bacteria growth } \\
\text { promoting effect (BGPE) }\end{array}$ & Reference \\
\hline $\begin{array}{c}\text { Red wine } \\
\text { grape extract }\end{array}$ & In vitro study & 2 weeks & $1000 \mathrm{mg}$ polyphenols/day & $\begin{array}{l}\text { SHIME and } \\
\text { qPCR/ } \\
\text { Pyrosequenc } \\
\text { ing }\end{array}$ & $\begin{array}{l}\text { - Bifidobacteria } \\
\text { - Blautia coccoides } \\
\text { - Anaeroglobus } \\
\text { - Subdoligranulum } \\
\text { - Bacteroides }\end{array}$ & $\begin{array}{l}\text { - Klebsiella sp. } \\
\text { - Alistipes } \\
\text { - Cloacibacillus } \\
\text { - Victivallis } \\
\text { - Akkermansia }\end{array}$ & 32 \\
\hline $\begin{array}{c}\text { Wine } \\
\text { polyphenols }\end{array}$ & Animal study & 15 weeks & $50 \mathrm{mg} / \mathrm{kg} \mathrm{bw}^{\mathrm{j}}$ & $\begin{array}{l}\text { Counting on } \\
\text { culture } \\
\text { medium } \\
\text { after faecal } \\
\text { inoculation }\end{array}$ & - Clostridium spp. & $\begin{array}{l}\text { - Bifidobacterium spp. } \\
\text { - Bacteroides } \\
\text { - Lactobacillus spp. }\end{array}$ & 38 \\
\hline
\end{tabular}

${ }^{a}$ FISH-FCM, Fluorescence in situ hybridization coupled to flow citometry; ${ }^{b} \mathrm{HCF}$, high- cocoa flavanol; ${ }^{\mathrm{c}} \mathrm{LCF}$, low- cocoa flavanol; ${ }^{\mathrm{d}} \mathrm{SHIME}$, Simulator of the Human Intestinal Microbiota Ecosystem; ${ }^{\mathrm{e}} \mathrm{qPCR}$, quantitative Polymerase Chain Reaction; ${ }^{\mathrm{f}} \mathrm{GT}$, green tea powder; ${ }^{\mathrm{g}} \mathrm{T}-\mathrm{RFLP}$, Terminal restriction fragment length polymorphism; ${ }^{\mathrm{h}} \mathrm{GTE}$, green tea extract; ${ }^{\mathrm{i}} \mathrm{DGGE}$, Denaturing gradient gel electrophoresis; ${ }^{\mathrm{j}}$ bw; body weight. 
Table 2. Polyphenol-rich Fruits and Vegetables (Soy, Pomegranate, Grapes, Berries, Apples) With Effects On Gut Microbiota

\begin{tabular}{|c|c|c|c|c|c|c|c|}
\hline $\begin{array}{l}\text { Food or food extracts rich } \\
\text { in polyphenols }\end{array}$ & Type of study & Duration & Dosis & $\begin{array}{l}\text { Techniques } \\
\text { used }\end{array}$ & $\begin{array}{l}\text { Antimicrobial activity } \\
\text { (AMA) }\end{array}$ & $\begin{array}{c}\text { Bacteria growth } \\
\text { promoting effect } \\
\text { (BGPE) }\end{array}$ & Reference \\
\hline Soygerm powder & In vitro study & 14 days & $2.5 \mathrm{~g} / \mathrm{day}$ & $\begin{array}{l}\text { SHIME }^{\mathrm{a}} \text { and } \\
\text { plate count }\end{array}$ & & -Lactobacillus spp. & 43 \\
\hline \multirow[t]{3}{*}{ Aqueous soy extract } & Animal study & 60 days & $\begin{array}{c}\mathrm{HUF}^{\mathrm{b}} \\
\left(2.8 \mathrm{~mL} / \mathrm{kg} \mathrm{bw}^{\mathrm{c}} / \mathrm{day}\right)\end{array}$ & $\begin{array}{l}\text { Plate count after } \\
\text { faecal } \\
\text { inoculation }\end{array}$ & $\begin{array}{l}\text { - Enterobacteria } \\
\text { - Clostridium spp. }\end{array}$ & -Enterococcus spp. & \\
\hline & & & $\begin{array}{c}\mathrm{HF}^{\mathrm{d}} \\
(2.8 \mathrm{~mL} / \mathrm{kg} \text { bw/day })\end{array}$ & & - Enterobacteria & $\begin{array}{l}\text {-Bifidobacterium } \\
\text { spp. } \\
\text {-Lactobacillus spp. } \\
\text {-Enterococcus spp. }\end{array}$ & 45 \\
\hline & & & $\begin{array}{l}\mathrm{HIF}^{\mathrm{e}}(2.8 \mathrm{~mL} / \mathrm{kg} \mathrm{bw}-2.1 \mathrm{mg} \text { of } \\
\text { total isoflavone/kg bw/day })\end{array}$ & & $\begin{array}{l}\text { - Enterobacteria } \\
\text { - Clostridium spp. }\end{array}$ & $\begin{array}{l}\text {-Bifidobacterium } \\
\text { spp. } \\
\text {-Lactobacillus spp. } \\
\text {-Enterococcus spp. }\end{array}$ & \\
\hline \multirow[t]{2}{*}{ Fermented soy product } & Animal study & 30 days & $\begin{array}{l}\text { Fermented soy product } \\
\text { ( } 3 \mathrm{~mL} / \mathrm{kg} \mathrm{bw} / \text { day })\end{array}$ & $\begin{array}{l}\text { Counting on } \\
\text { culture medium } \\
\text { after faecal } \\
\text { inoculation }\end{array}$ & & $\begin{array}{l}\text {-Enterococci } \\
\text {-Lactobacillus spp. } \\
\text { - Bacteroides spp. }\end{array}$ & 44 \\
\hline & & & $\begin{array}{l}\text { Unfermented soy product } \\
\qquad(3 \mathrm{~mL} / \mathrm{kg} \mathrm{bw} / \text { day })\end{array}$ & & $\begin{array}{l}\text { - Clostridium spp. } \\
\text { - Bifidobacterium spp. }\end{array}$ & -Lactobacillus spp. & \\
\hline
\end{tabular}




\section{Table 2. Continued}

\begin{tabular}{|c|c|c|c|c|c|c|c|}
\hline $\begin{array}{l}\text { Food or food extracts rich } \\
\text { in polyphenols }\end{array}$ & Type of study & Duration & Dosis & $\begin{array}{l}\text { Techniques } \\
\text { used }\end{array}$ & $\begin{array}{c}\text { Antimicrobial activity } \\
\text { (AMA) }\end{array}$ & $\begin{array}{c}\text { Bacteria growth } \\
\text { promoting effect } \\
\text { (BGPE) }\end{array}$ & Reference \\
\hline \multirow[t]{2}{*}{ Soy- milk } & $\begin{array}{l}\text { Human } \\
\text { intervention }\end{array}$ & 3 moths & $\begin{array}{l}\text { Low glycinin soymilk } \\
500 \mathrm{~mL} / \text { day }\end{array}$ & $\begin{array}{l}\mathrm{qPCR}^{\mathrm{f}} \text { and FLX } \\
\text { pyrosequencing }\end{array}$ & $\begin{array}{l}\text { - Bifidobacterium } \\
\text { - Firmicutes }\end{array}$ & $\begin{array}{l}\text {-Bacteroides- } \\
\text { Prevotella } \\
\text {-Bacteroidetes } \\
\text {-Proteobacteria }\end{array}$ & 41 \\
\hline & & & $\begin{array}{c}\text { Conventional soymilk } \\
500 \mathrm{~mL} / \text { day }\end{array}$ & & $\begin{array}{l}\text { - Bifidobacterium } \\
\text { - Firmicutes }\end{array}$ & $\begin{array}{l}\text {-Bacteroidetes } \\
\text {-Proteobacteria }\end{array}$ & \\
\hline Soy- milk & $\begin{array}{l}\text { Human } \\
\text { intervention }\end{array}$ & 1 month & Exclusive feeding & PCR- DGGE ${ }^{\mathrm{g}}$ & & $\begin{array}{l}\text {-Bifidobacterium } \\
\text { infantis } \\
\text {-Bifidobacterium } \\
\text { longum } \\
\text {-Bifidobacterium } \\
\text { breve } \\
\text {-Bifidobacterium } \\
\text { adolescentis }\end{array}$ & 42 \\
\hline $\begin{array}{l}\text { Pomegranate } \\
\text { by-product }\end{array}$ & In vitro study & $\begin{array}{c}0-48 \mathrm{~h} \\
\text { incubation }\end{array}$ & $1.5 \mathrm{~mL}$ of $\mathrm{PPE}^{\mathrm{h}}$ & $\begin{array}{l}\text { Batch culture } \\
\text { fermentationmo } \\
\text { del / } \text { FISH }^{\mathrm{i}}\end{array}$ & & $\begin{array}{l}\text {-Lactobacillus- } \\
\text { Enterococcus } \\
\text { group } \\
\text {-Bifidobacterium } \\
\quad \text { spp. }\end{array}$ & 27 \\
\hline Pomegranate extract & Animal study & 25 days & $250 \mathrm{mg} / \mathrm{kg}$ & $\begin{array}{c}\text { Agar plate } \\
\text { dilution method }\end{array}$ & $\begin{array}{l}\text { - Escherichia coli } \\
\text { - Enterobacteria }\end{array}$ & $\begin{array}{l}\text { ctobacilli } \\
\text { fidobacteria } \\
\text { ostridium }\end{array}$ & 46 \\
\hline Pomegranate peel extract & Animal study & 4 week & $0.2 \%$ (6 mg/day) & qPCR & & $\begin{array}{l}\text { cteroides- Prevotella } \\
\text { spp. } \\
\text { idobacterium spp. }\end{array}$ & 47 \\
\hline
\end{tabular}


Table 2. Continued

\begin{tabular}{|c|c|c|c|c|c|c|c|}
\hline $\begin{array}{l}\text { Food or food extracts rich } \\
\text { in polyphenols }\end{array}$ & Type of study & Duration & Dosis & $\begin{array}{l}\text { Techniques } \\
\text { used }\end{array}$ & $\begin{array}{l}\text { Antimicrobial activity } \\
\text { (AMA) }\end{array}$ & $\begin{array}{c}\text { Bacteria growth } \\
\text { promoting effect } \\
\text { (BGPE) }\end{array}$ & Reference \\
\hline Pomegranate by-product & In vitro study & $\begin{array}{c}0-72 \mathrm{~h} \\
\text { incubation }\end{array}$ & $0.01 \%(\mathrm{v} / \mathrm{v})$ of PPE & $\begin{array}{l}\text { Counting on } \\
\text { culture medium }\end{array}$ & $\begin{array}{l}\text { - Clostridium perfringens } \\
\text { NRRL B-23584 } \\
\text { - Clostridium ramosum } \\
\text { NRRL B-23617 } \\
\text { - Staphylococcus aureus } \\
\text { ATCC } 29213 \\
\text { - Lactobacillus acidophilus } \\
\text { NRRL B-4495 } \\
\text { - Lactobacillus pentosus } \\
\text { NRRL B-227 } \\
\text { - Lactobacillus rhamnosus } \\
\text { NRRL B-442 } \\
\text { - Bifidobacterium bifidum } \\
\text { NRRL B-41410 }\end{array}$ & $\begin{array}{l}\text {-Bifidobacterium } \\
\text { infantis NRRL } \\
\text { B-41661 } \\
\text {-Bifidobacterium } \\
\text { breve NRRL B- } \\
\text { 41408 }\end{array}$ & 26 \\
\hline Grape seed extract & In vitro study & $\begin{array}{c}24-48 \mathrm{~h} \\
\text { incubation }\end{array}$ & $\begin{array}{c}\text { GSE-O }^{\mathrm{k}} \\
\text { (279 } \mathrm{mg} / \mathrm{g} \text { total phenolics) } \\
\text { at } 0.25-1 \mathrm{mg} / \mathrm{mL}\end{array}$ & $\begin{array}{l}\text { Culture medium } \\
\text { Spectrophotome } \\
\text { try }(600 \mathrm{~nm})\end{array}$ & $\begin{array}{l}\text { - Streptococcus thermophilus } \\
\text { STY-31 } \\
\text { - Lactobacillus fermentum } \\
\text { PNA1 } \\
\text { - Lactobacillus fermentum } \\
\text { LC-40 } \\
\text { - Lactobacillus acidophilus } \\
\text { LA-5 } \\
\text { - Lactobacillus vaginalis } \\
\text { ZL63-22 } \\
\text { - Bifidobacterium lactis } \\
\text { BB12 }\end{array}$ & $\begin{array}{l}\text { - Bifidobacterium } \\
\text { breve 26M2 } \\
\text {-Bifidobacterium } \\
\text { bifidum HDD541 } \\
\text {-Lactobacillus } \\
\text { plantarum } \\
\text { IFPL935 } \\
\text {-Lactobacillus casei } \\
\text { IFPL7190 } \\
\text {-Lactobacillus } \\
\text { bulgaricus LBY- } \\
27\end{array}$ & 55 \\
\hline
\end{tabular}


Table 2. Continued

\begin{tabular}{|c|c|c|c|c|c|c|c|}
\hline $\begin{array}{l}\text { Food or food extracts rich } \\
\text { in polyphenols }\end{array}$ & Type of study & Duration & Dosis & $\begin{array}{c}\text { Techniques } \\
\text { used }\end{array}$ & $\begin{array}{c}\text { Antimicrobial activity } \\
\text { (AMA) }\end{array}$ & $\begin{array}{c}\text { Bacteria growth } \\
\text { promoting effect } \\
\text { (BGPE) }\end{array}$ & Reference \\
\hline Grape seed extract & In vitro study & $\begin{array}{c}18-24 \mathrm{~h} \\
\text { incubation }\end{array}$ & $\begin{array}{c}\text { Acetone: water: acetic acid } \\
(90: 9.5: 0.5), 667.87 \mathrm{mg} \\
\text { GAE } / \mathrm{g} \\
\text { At } 20 \% \\
\text { Ethyl acetate:methanol: } \\
\text { water }(60: 30: 10), 627.98 \\
\text { mg GAE/g } \\
\text { At } 20 \%\end{array}$ & $\begin{array}{c}\text { Paper disc } \\
\text { diffusion } \\
\text { method }\end{array}$ & $\begin{array}{l}\text { - Aeromonas hydrophila } \\
\text { ATCC } 7965 \\
\text { - Bacillus brevis FMC } 3 \\
\text { - Bacillus cereus FMC } 19 \\
\text { - Bacillus megaterium } \\
\text { DSM } 32 \\
\text { - Bacillus subtilis IMG } 22 \\
\text { - Enterobacter aerogenes } \\
\text { CCM2531 } \\
\text { - Enterococcus faecalis } \\
\text { ATCC } 15753 \\
\text { - Escherichia coli DM } \\
\text { - Klebsiella pneumoniae } \\
\text { FMC } 5 \\
\text { - Listeria monocytogenes } \\
\text { Scott A } \\
\text { - Mycobacterium } \\
\text { smegmatis RUT } \\
\text { - Proteus vulgaris FMC } 1 \\
\text { - Pseudomonas } \\
\text { aeruginosa ATCC } \\
\text { 27853 } \\
\text { - Staphylococcus aureus } \\
\text { COWAN 1 }\end{array}$ & & 54 \\
\hline
\end{tabular}




\section{Table 2. Continued}

\begin{tabular}{|c|c|c|c|c|c|c|c|}
\hline $\begin{array}{l}\text { Food or food extracts rich } \\
\text { in polyphenols }\end{array}$ & Type of study & Duration & Dosis & $\begin{array}{l}\text { Techniques } \\
\text { used }\end{array}$ & $\begin{array}{l}\text { Antimicrobial activity } \\
\text { (AMA) }\end{array}$ & $\begin{array}{c}\text { Bacteria growth } \\
\text { promoting effect } \\
\text { (BGPE) }\end{array}$ & Reference \\
\hline $\begin{array}{l}\text { Proanthocyanidin-rich } \\
\text { grape seed extract }\end{array}$ & $\begin{array}{l}\text { Human } \\
\text { intervention }\end{array}$ & 2 weeks & $\begin{array}{c}0.5 \mathrm{~g} / \text { day/subject extract } \\
(0.19 \mathrm{~g} / \text { day/subject as } \\
\text { proanthocyanidins })\end{array}$ & $\begin{array}{l}\text { Counting on } \\
\text { culture medium } \\
\text { after faecal } \\
\text { inoculation }\end{array}$ & - Enterobacteriaceae & -Bifidobacterium & 58 \\
\hline \multirow[t]{2}{*}{$\begin{array}{l}\text { Grape antioxidant dietary } \\
\text { fiber }\end{array}$} & In vitro study & $\begin{array}{l}22-26 \mathrm{~h} \\
\text { incubation }\end{array}$ & $\begin{array}{c}\text { Non-Extractable } \\
\text { polyphenols } \\
2.4 \mathrm{mg} / \mathrm{mL}\end{array}$ & Plate count & & $\begin{array}{l}\text {-Lactobacillus } \\
\text { reuteri ATCC } \\
23272 \\
\text {-Lactobacillus } \\
\text { acidophilus } \\
\text { ATCC } 4356\end{array}$ & 57 \\
\hline & Animal study & 4 weeks & $\begin{array}{c}50 \mathrm{~g} / \mathrm{kg} \text { diet } \\
(4.23 \mathrm{~g} / 100 \mathrm{~g} \text { Extractable } \\
\text { polyphenols; } 17.51 \mathrm{~g} / 100 \mathrm{~g} \\
\text { Non Extractable } \\
\text { polyphenols })\end{array}$ & RT-PCR & - Bifidobacterium spp. & -Lactobacillus spp. & \\
\hline \multirow[t]{3}{*}{$\begin{array}{l}\text { Grape pomace cocentrate } \\
\text { and grape seed extract }\end{array}$} & In vitro study & $\begin{array}{c}24 \mathrm{~h} \\
\text { incubation }\end{array}$ & GSE (7.2 g/kg) & $\begin{array}{l}\text { Paper disc } \\
\text { diffusion } \\
\text { method }\end{array}$ & $\begin{array}{c}\text { - Clostridium perfringens } \\
\text { BA05/00439- 5B }\end{array}$ & & \\
\hline & Animal study & 21 days & $\mathrm{GPC}^{\mathrm{m}}(60 \mathrm{~g} / \mathrm{kg})$ & T-RFLP ${ }^{\mathrm{n}}$ & $\begin{array}{l}\text {-Pseudomonas/Acinobacter } \\
\text { spp. }\end{array}$ & $\begin{array}{l}\text { - Bacillus/Paenibacill } \\
\text { us spp } \\
\text { - Desulfitobacterium } \\
\text { hafniense }\end{array}$ & 56 \\
\hline & & & GSE $(7.2 \mathrm{~g} / \mathrm{kg})$ & & & $\begin{array}{l}\text {-Pseudomonas/Acino } \\
\text { bacter spp. } \\
\text {-Nocardioides spp. } \\
\text {-Bacillus/Paenibacill } \\
\text { us spp. } \\
\text {-Desulfitobacterium } \\
\text { hafniense }\end{array}$ & \\
\hline
\end{tabular}


Table 2. Continued

\begin{tabular}{|c|c|c|c|c|c|c|}
\hline $\begin{array}{l}\text { Food or food extracts rich } \\
\text { in polyphenols }\end{array}$ & Type of study & Duration & Dosis & $\begin{array}{l}\text { Techniques } \\
\text { used }\end{array}$ & $\begin{array}{c}\text { Antimicrobial activity } \\
\text { (AMA) }\end{array}$ & $\begin{array}{r}\text { Bacteria gro } \\
\text { promoting e } \\
\text { (BGPE) }\end{array}$ \\
\hline Wild blueberry & $\begin{array}{l}\text { Human } \\
\text { intervention }\end{array}$ & 6 weeks & $25 \mathrm{~g} /$ day & RT-PCR & & $\begin{array}{l}\text {-Lactobacillus } \\
\text { acidophilus } \\
\text { - Bifidobacteriun } \\
\text { spp. }\end{array}$ \\
\hline \multirow[t]{2}{*}{$\begin{array}{c}\text { Blackurrant extract } \\
\text { powder }\end{array}$} & Animal study & 4 weeks & $\begin{array}{l}\text { Blackcurrant extract } \\
\text { powder } \\
13.4 \mathrm{mg} / \mathrm{kg} \mathrm{bw} / \text { day }\end{array}$ & FISH & $\begin{array}{l}\text { - Bacteroides } \\
\text { - Clostridium } \\
\text { perfringens/histolyticum } \\
\text { sub. grp. }\end{array}$ & $\begin{array}{l}\text {-Bifidobacteria } \\
\text {-Lactobacilli }\end{array}$ \\
\hline & & & $\begin{array}{c}\text { Blackcurrant extract } \\
\text { powder, lactoferrin and } \\
\text { lutein } \\
30 \mathrm{mg} / \mathrm{kg} \mathrm{bw} / \text { day }\end{array}$ & & $\begin{array}{l}\text { - Bacteroides } \\
\text { - Clostridium perfringens/ } \\
\text { histolyticum sub. grp. }\end{array}$ & -Bifidobacteria \\
\hline Berry extracts & In vitro study & $\begin{array}{l}12-24 \mathrm{~h} \\
\text { incubation }\end{array}$ & $\begin{array}{l}1-5 \mathrm{mg} / \mathrm{mL} \\
\text { Cloudberry } \\
\text { Raspberry }\end{array}$ & $\begin{array}{l}\text { Counting on } \\
\text { culture medium }\end{array}$ & $\begin{array}{l}\text { - Staphylococcus aureus E- } \\
70045 \\
\text { - Salmonella enterica sv. } \\
\text { Typhimurium E-981151 } \\
\text { - Salmonella enterica sv. } \\
\text { Infantis E-97738 }\end{array}$ & \\
\hline
\end{tabular}


Table 2. Continued

\begin{tabular}{|c|c|c|c|c|c|c|c|}
\hline $\begin{array}{l}\text { Food or food extracts rich } \\
\text { in polyphenols }\end{array}$ & Type of study & Duration & Dosis & $\begin{array}{c}\text { Techniques } \\
\text { used }\end{array}$ & $\begin{array}{c}\text { Antimicrobial activity } \\
\text { (AMA) }\end{array}$ & $\begin{array}{c}\text { Bacteria growth } \\
\text { promoting effect } \\
\text { (BGPE) }\end{array}$ & Reference \\
\hline \multirow[t]{4}{*}{ Berry extracts } & In vitro study & $\begin{array}{c}12-24 \mathrm{~h} \\
\text { incubation }\end{array}$ & $\begin{array}{c}0.8-3.5 \mathrm{mg} / \text { well } \\
\text { Blueberry }\end{array}$ & $\begin{array}{l}\text { Agar diffusion } \\
\text { method }\end{array}$ & $\begin{array}{l}\text { - Escherichia coli } 50 \\
\text { - Escherichia coli CM871 } \\
\text { - Lactobacillus rhamnosus E- } \\
\quad 666 \\
\text { - Lactobacillus rhamnosus E- } \\
\quad 800 \\
\text { - Salmonella enterica } \mathrm{SH}- \\
\quad 5014\end{array}$ & & \\
\hline & & & Raspberry & & $\begin{array}{l}\text { - Lactobacillus rhamnosus } \\
\quad \text { E-666 } \\
\text { - Lactobacillus rhamnosus E- } \\
\quad 800 \\
\text { - Lactobacillus reuteri E-849 } \\
\text { - Escherichia coli } 50 \\
\text { - Escherichia coli CM871 } \\
\text { - Salmonella enterica SH- } \\
\quad 5014\end{array}$ & & 59 \\
\hline & & & Cloudberry & & $\begin{array}{l}\text { - Lactobacillus rhamnosus E- } \\
\quad 666 \\
\text { - Escherichia coli } 50 \\
\text { - Escherichia coli CM871 } \\
\text { - Salmonella enterica SH- } \\
5014 \\
\text { - Enterococcus faecalis E- } \\
203 \\
\text { - Bifidobacterium lactis E- } \\
508\end{array}$ & & \\
\hline & & & Strawberry & & $\begin{array}{l}\text { - Escherichia coli CM871 } \\
\text { - Bifidobacterium lactis E- } \\
508\end{array}$ & & \\
\hline
\end{tabular}


Table 2. Continued

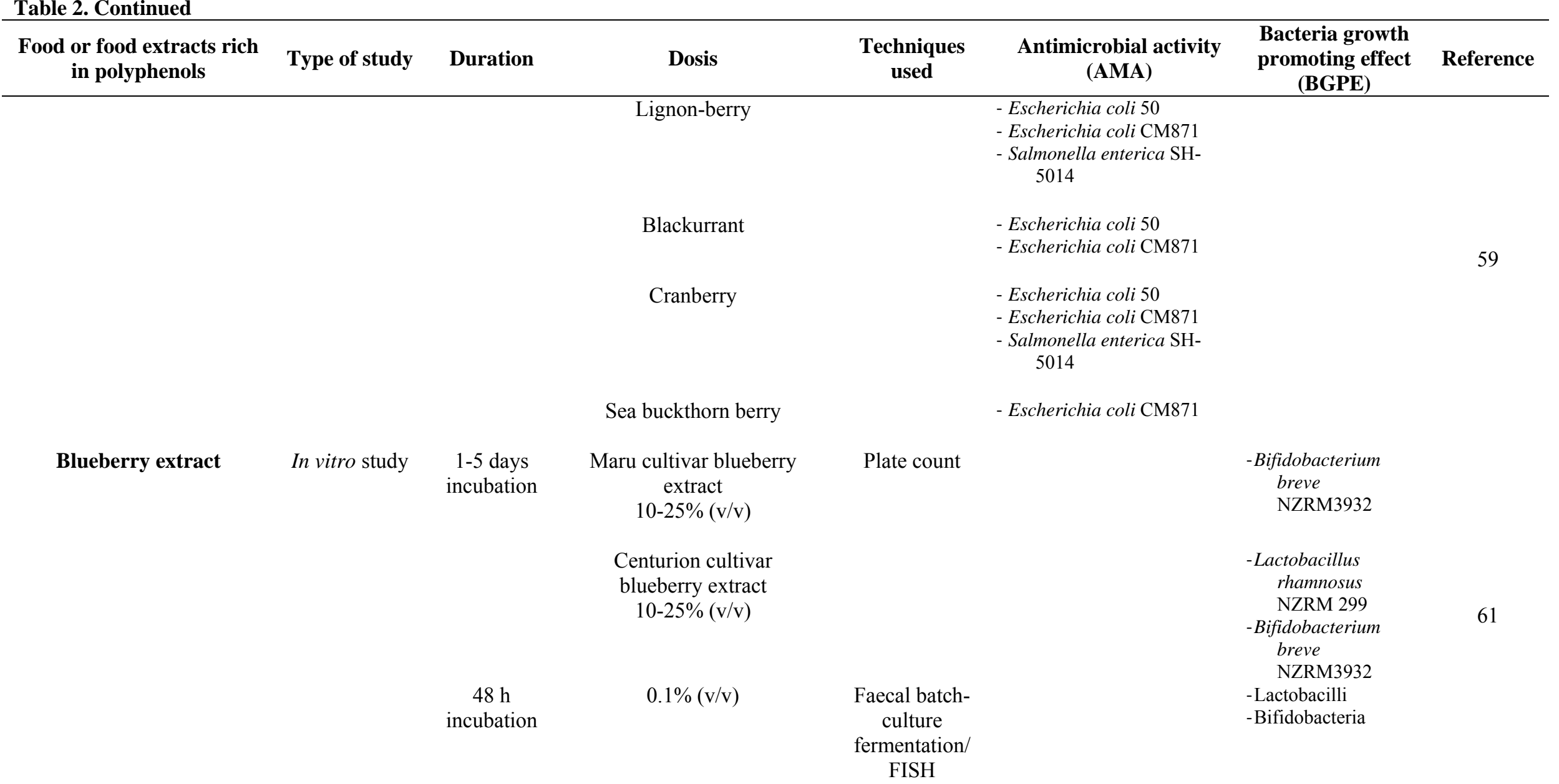


Table 2. Continued

\begin{tabular}{|c|c|c|c|c|c|c|c|}
\hline $\begin{array}{l}\text { Food or food extracts rich } \\
\text { in polyphenols }\end{array}$ & Type of study & Duration & Dosis & $\begin{array}{l}\text { Techniques } \\
\text { used }\end{array}$ & $\begin{array}{l}\text { Antimicrobial activity } \\
\text { (AMA) }\end{array}$ & $\begin{array}{c}\text { Bacteria growth } \\
\text { promoting effect } \\
\text { (BGPE) }\end{array}$ & Reference \\
\hline \multirow[b]{5}{*}{ Apples and apple products } & Animal study & 6 days & $\begin{array}{c}4 \mathrm{~mL} / \mathrm{kg} \text { bw/day from Maru } \\
\text { cultivar }\end{array}$ & FISH & & $\begin{array}{l}\text {-Lactobacilli } \\
\text {-Bifidobacteria }\end{array}$ & \multirow{4}{*}{61} \\
\hline & & & & & & & \\
\hline & & & $4 \mathrm{~mL} / \mathrm{kg}$ bw/day from & & & -Lactobacilli & \\
\hline & & & Centurion cultivar & & & -Bifidobacteria & \\
\hline & Animal study & 14 weeks & $10 \mathrm{~g} /$ day raw whole apple & $\begin{array}{l}\text { PCR-DGGE } \\
\text { and qPCR }\end{array}$ & - Bacteroides & & 48 \\
\hline Apple juice & Animal study & 4 weeks & Free access & Plate count & & $\begin{array}{l}\text {-Bifidobacterium } \\
\text {-Lactobacillus }\end{array}$ & 49 \\
\hline Apple juice colloid & Animal study & 6 weeks & Free Access & $\begin{array}{c}\text { Faecal } \\
\text { inoculation and } \\
\text { plate count }\end{array}$ & & -Bacteroidaceae & 50 \\
\hline
\end{tabular}


Table of Contents/Abstract Graphics

POLYPHENOLS (flavonoids and nonflavonoids)

POLYPHENOL-RICH DIETARY SOURCES

(cocoa, tea, wine, soy products, fruits)

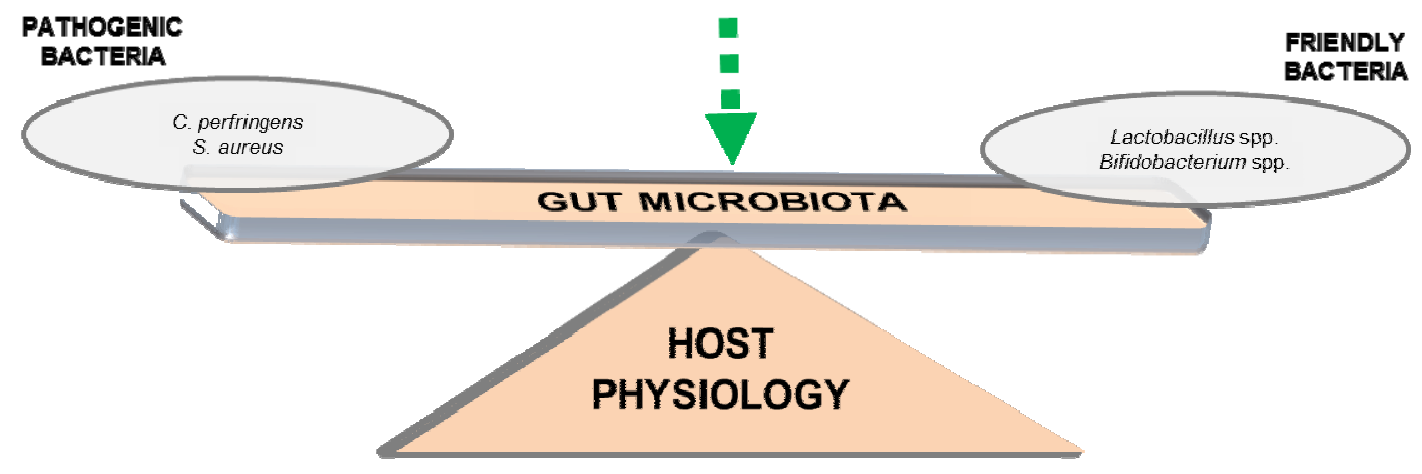

